\title{
PLANT SPECIES RICHNESS IN FRAGMENTED AGRICULTURAL LANDSCAPE - META-ANALYSIS
}

\author{
SARAN, E.* - DUSZA-ZWOLIŃSKA, E. - GAMRAT, R. \\ Department of Ecology, Environmental Protection and Management, West Pomeranian \\ University of Technology \\ al. Piastów 17, 70-310 Szczecin, Poland \\ *Corresponding author \\ e-mail: edyta.saran@zut.edu.pl \\ (Received $2^{\text {nd }}$ Oct 2018; accepted $28^{\text {th }}$ Nov 2018)
}

\begin{abstract}
Fragmentation of agricultural landscape is considered as a threat to biodiversity of many important habitats around the world. Change to the use of land causing loss, isolation and degradation of ecosystems, is one of the main subjects of study in the field of ecology and conservation biology. An appropriate and complex analysis of factors shaping species diversity of the objects in fragmented agricultural landscape may contribute to the understanding and limiting the negative impact of this phenomenon on biocenosis. This paper is a meta-analysis in order to determine the applied research methods and a synthetic representation of the impact of landscape fragmentation on various spatial objects. The aim of the study was to analyse the main assumption of The Theory of Island Biogeography which states that with the decrease of the area of objects, their biodiversity will decrease, while their isolation will increase. An attempt was also made to assess the impact of particular factors that may affect the plant species richness in given objects. The meta-analysis was carried out on the basis of selected criteria for 41 scientific articles in European countries. It was assumed that one cannot unequivocally state the correctness of applying this theory to any type of objects. The conducted study indicated that usually the greatest positive influence on phytodiversity has the size of a given patch, while isolation was assigned a negative impact. The review of landscape research confirmed the thesis that the surface and isolation cannot be unambiguously determined to shape biodiversity in the patches.
\end{abstract}

Keywords: landscape fragmentation, rural landscape, phytodiversity, patch metrics, landscape metrics

\section{Introduction}

Over the last centuries, the deforestation and transformation of other ecosystems into farming land as well as forestation of empty or unused areas caused changes to biodiversity in the substantial area of Europe (Vellend et al., 2007). By the end of the nineteenth century, traditional farming prevailed, however it changed over years, focusing on cultivation of cereals (Luoto et al., 2003). The development of agriculture has led to the expansion of arable land and fragmentation of natural biocenoses, which in turn is considered the greatest threat to biodiversity (Montis et al., 2017).

Tscharntke et al. (2005) consider that intensification of farming takes place on two spacial scales: local and connected with the landscape (e.g. converting meadows into farming land, applying monocultures or fragmentation of natural habitats), whereby landscape scale reflects local consequences of enhanced farming practices. It is believed that local intensification is most of all the use of agrochemicals, an increase of the area subject to cultivation, shallowing and drying of mid-field ponds, closing outflows of drainage ditches as well as mechanisation of farming (Bratli et al., 2006). However, agricultural landscape does not consist of the cropland, but also of meadows, forest patches, midfield islets, baulks, roadverges, heathland or ponds (Williams et al., 2004; 
Aavik and Lira, 2010). Midfield islets and roadverges are considered as small remnant grassland habitats typical for contemporary agriculture landscape (Cousins, 2006).

The patches of natural or semi-natural vegetation preserved till today form the socalled environmental islands, which are a refuge for many species of plants and animals (Bosiacka and Pieńkowski, 2004). In addition, urban and infrastructural expansion, which is the hallmark of the modern world, has an important impact on the landscape (Krausmann et al., 2003; Luo et al., 2015).

In a modern world, whose defining characteristic is increasingly urban and infrastructural expansion, natural environmental processes are subject to successive degradation. For this very reason, optimization of activities with a purpose of rational management of environmental resources and the protection of landscape in the spirit of sustainable development (Irvinea et al., 2009) has become one of the important tasks (Degórski, 2015; Wiedmann et al., 2012).

Landscape is defined as an area, perceived by people, whose character results from actions and interactions of environmental or anthropogenic factors, which constitutes an important component of the quality of life of a society, both in urban and rural areas and in the areas with high level of degradation or in areas of high natural values (Chmielewski et al., 2015; Richling and Solon, 2011).

The definitions of landscape used around the world may be systematized by dividing them into two categories: visual (i.e. the idea of a picture) and physical or geographical (Longatti and Dalang, 2007; Richling and Solon, 2011). Landscape within geographical meaning is a part of environment constituting of patches, corridors and matrix. Matrix is understood as a structural component (or a set of similar structural components), most commonly distinguished in the categories of land cover, which: (a) dominates the area of the local landscape (b) its special location is such that it combines all most distant cut-off points of a local landscape, (c) it constitutes the surroundings of the majority of the remaining spacious components of the local landscape (Solon et al., 2015; Pieńkowski and Podlasiński, 2017). Matrix may constitute habitat for some indigenous species (Fisher and Lindenmayer, 2007) and it allows them to move through corridors among patches (Ricketts, 2001). The conditions of the matrix determine the scope of environmental factors, which model the structure and the processes taking place in a given patch. It is thought that the type and the quality of the matrix is essential in determining the abundance and species composition within the objects (Ewers and Didham, 2006). However, in fact, blurring of distinctions between species inhabiting the fragments and the habitat of a matrix is a common occurrence. "The blurring" of species is most common in small objects and on the edges of big patches, which may disrupt the form of a given area and the outline of the isolation effect (Cook et al., 2002).

Landscape fragmentation, in particular rural landscape, is considered one of the main causes of a decrease in plant species diversity, which may in time lead to extinction of many valuable species (Quine and Watts, 2009; Montis et al., 2017; Qi et al., 2017). The division of environment, caused mainly by anthropogenic activities, leads to the creation of small and isolated objects and the separation of ecotone zones on their edges, which disturbs the integrity of these ecosystems (Heinken and Weber, 2013; Lindborg et al., 2014). The consequence of this phenomenon is a disturbance of the process of genetic information exchange among increasingly smaller populations (Ibáñez et al., 2014).

In order to systematize research on fragmentation, many theoretical assumptions and landscape models are analyzed, which may be helpful in a better understanding of 
processes taking place in the landscape (Fischer and Lindenmayer, 2007; Fardila et al., 2017). The most widespread is the conceptual model of habitat fragmentation based on The Theory of Island Biogeography (MacArthur and Wilson, 1967). MacArthur and Wilson (1967) were the first to assume, that a decrease in the area of habitats will lead to a decrease of biodiversity, whereas their isolation will increase (Kattan and Murcia, 2003). According to The Theory of Islands Biogeography, an area is the main physical parameter which has a positive influence on biodiversity of a given object. However, so far it has not been established conclusively, to what extent an increase of a patch area or of the number of habitats in a patch, affects the abundance and species diversity. Patch isolation is characteristic for landscape fragmentation, which is said to affect negatively the richness of species as it reduces their dispersion (Karger et al., 2014). This model led to the development of more complex methods of classifying landscapes, such as the patch-corridor-matrix model (Forman and Gordon, 1981) and the landscape mosaic model (Wiens, 1995).

Due to the awareness of the danger connected with landscape fragmentation, there is a lot of research conducted for the purpose of defining its actual impact on plant species diversity (Iida et al., 1995; Haig et al., 2000; Hanski, 2005; Cangolo et al., 2006). There is also research conducted with respect to the influence of environment homogenization on fauna, inclusive of insects (Löffler and Fartmann, 2017), e.g. ants (Dauber et al., 2006), butterflies (Ricketts, 2001), mammals (Vieira et al., 2009), e.g. bats (FuentesMontemayor et al., 2013); birds (Carrara et al., 2015), reptiles and amphibians (Watling and Donnelly, 2008). There is also experimental research conducted, in artificially created environment (Cook et al., 2002; Collins et al., 2009; Allan et al., 2015), where the aim of the study is purposeful manipulation of the landscape. In such artificially created conditions, it is often not possible to check some of the features of the particular objects studied, e.g. their shape, degree of replication, site initiation and position on the landscape (Debinski and Holt, 1999). Due to the awareness of negative impact of fragmentation on the richness of species of ecosystems, many habitats are recreated and analysis of the effectiveness of such approach is performed on them. These analyses show positive impact of habitats restitution not only on the biodiversity in objects restored but also in their surroundings (Prach et al., 2015; Conradi and Kollmann, 2016; Waldén et al., 2017).

In this study, the main assumption of The Theory of Island Biogeography was analyzed, based on the example of landscape studies, which states that with the decrease of the area of objects, their biodiversity will decrease, while their isolation will increase. An attempt was also made to assess the impact of particular factors that may affect the plant species richness in given objects, with particular emphasis on the landscape matrix. For this purpose: (1) the research methods used in the implementation of landscape studies were analyzed, (2) the collected information was compared, and (3) the obtained results were synthetically presented. The meta-analysis included papers in the field of ecology and biology conservation, including articles published in 1997 2018 in Europe (15 countries, 41 papers).

\section{Materials and methods}

For the purpose of analysing the influence of fragmentation on the diversity of plant species and comparing research methods, in December 2017 and in January 2018, a systematic search of the source literature was carried out. The search of papers was 
divided into two categories: 1) English- language papers included in ScienceDirect, Wiley Online Library and SpringerLink databases and 2) papers published in selected, Polish scientific topic journals (Dissertations of Cultural Landscape Commission, Hydrobiology, Polish Journal of Ecology, Water-Environment-Rural Areas, Scientific Papers of the University of Life Sciences in Wroctaw. Agriculture). The existing Polish databases of papers do not allow a complex search of papers with use of sets of keywords. For this reason the Polish publications were selected based on a review of the journals, whose topics include studies on the structure and functioning of the landscape.

All papers found in the English-language databases were searched for with use of the following keywords (in various configurations): 'biodiversity', 'connectivity', 'habitat fragmentation', 'habitat loss', 'isolation', 'landscape fragmentation', 'matrix', 'small habitats', 'species richness' (Table 1). On that basis, the first, preliminary selection of the papers was made. The table below presents all the keywords used and their definitions.

Table 1. Selected keywords and their definitions

\begin{tabular}{|c|c|c|}
\hline Term & Definition & References \\
\hline Biodiversity & $\begin{array}{l}\text { 'the variety of life and its processes; it } \\
\text { includes the variety of living organisms, the } \\
\text { genetic differences among them, the } \\
\text { communities and ecosystems in which they } \\
\text { occur, and the ecological and evolutionary } \\
\text { processes that keep them functioning, yet } \\
\text { ever changing and adapting' }\end{array}$ & $\begin{array}{l}\text { DeLong, } 1996 \text { for Noss and } \\
\text { Cooperrider, } 1994\end{array}$ \\
\hline Connectivity & $\begin{array}{l}\text { 'measure of landscape structure; the degree to } \\
\text { which the landscape facilitates or impedes } \\
\text { movement among resource patches' }\end{array}$ & Taylor et al., 1993 \\
\hline $\begin{array}{c}\text { Habitat } \\
\text { fragmentation }\end{array}$ & $\begin{array}{l}\text { 'breaking apart of a large area of habitat into } \\
\text { several smaller areas' }\end{array}$ & $\begin{array}{l}\text { Lindenmayer and Fischer, } \\
2006\end{array}$ \\
\hline Habitat loss & $\begin{array}{l}\text { 'loss of habitat for a given species from an } \\
\text { area, precluding that taxon from persisting } \\
\text { there; viz the area becomes nonhabitat for that } \\
\text { species' }\end{array}$ & $\begin{array}{l}\text { Lindenmayer and Fischer, } \\
2006\end{array}$ \\
\hline Isolation & $\begin{array}{l}\text { 'distance to another patch and areas of } \\
\text { patches' } \\
\text { 'disrupts species distribution patterns and } \\
\text { forces dispersing individuals to traverse a } \\
\text { matrix habitat that separates suitable habitat } \\
\text { fragments from each other; defined by the } \\
\text { Euclidean distance between habitat } \\
\text { fragments' }\end{array}$ & $\begin{array}{c}\text { Graae, } 2000 \\
\text { Ewers and Didham, } 2006\end{array}$ \\
\hline $\begin{array}{c}\text { Landscape } \\
\text { fragmentation }\end{array}$ & $\begin{array}{l}\text { 'landscape characterized by a strong contrast } \\
\text { between native vegetation patches and their } \\
\text { surrounding matrix' }\end{array}$ & Mortelliti et al., 2010 \\
\hline Matrix & 'the area between the habitable patches' & Debinski, 2006 \\
\hline Small habitats & $\begin{array}{l}\text { 'patches found outside protected areas, such } \\
\text { as road verges, shading trees, mid-field islets } \\
\text { and cropland set aside' }\end{array}$ & Lindborg et al., 2014 \\
\hline Species richness & $\begin{array}{l}\text { 'the number of different species occurring in } \\
\text { some location or under some condition such } \\
\text { as pollution' }\end{array}$ & DeLong, 1996 \\
\hline
\end{tabular}


Selected articles were chosen based on the indication of Fardila et al. (2017), who conducted a detailed meta-analysis in relation to the impact of fragmentation on the species richness of all living organisms. They suggested that there is a need to better integrate studies published in languages other than English with the broader international literature. Fardila et al. (2017) reviewed only papers written in English and as they indicate this might have biased the geographic distribution of the studies they sampled. Therefore, among others, the authors of this paper limited their research to European literature covering only the world of plants, which enabled the described analyses to be carried out. The paper refers not only to English-language works, but also research of Polish scientists was used, enabling preliminary analysis of the existing trend in research on the structure and functioning of the landscape. It is worth noting that access to polish-language works is quite limited due to the lack of their English translation.

The selection of papers (the Polish ones and those available from the Englishlanguage literature databases) was based on the following criteria: in the contents of the paper the landscape had to be defined as agricultural or at least partially connected with agricultural landscape, the study had to involve plant species and must have been conducted in the Western European countries. Experimental research was excluded though, as it presents test results obtained through a purposeful manipulation of the landscape. The authors of the paper wanted to present research findings connected with the objects which are naturally present in the agricultural landscape. Based on the aforementioned criteria, the analysis involved in total 41 studies published between years 1997-2018 in 15 European countries, namely: Austria, Belgium, Denmark, Estonia, Finland, France, the Netherlands, Luxembourg, Germany, Norway, Poland, Portugal, Sweden, Great Britain and Italy.

Each paper analysed was classified in the context of 5 features: 1) type of study, 2) study design (location, patch area, its type and number), 3) source of floristic data (research, inclusive of field research), 4) main metrics (variables involved in the research) and 5) data analysis (own work based on Fardila et al., 2017) (Figure 1).

While analysing the "data analysis" category in each paper, it was verified whether the authors included in their research the following items: Geographical Information System (GIS), statistical calculations and the method of defining species richness (the total number of species and the application of biodiversity measurement indices).

The publications were also divided into ten categories connected with the main aims of study related to the influence of a given factor on the richness of plant species: (1) species richness affected by fragmentation; (2) interior and edge, (3) isolation, (4) patch attributes, (5) habitat conditions, (6) landscape structure, (7) dispersion, (8) fragmentation in time, (9) abandonment, (10) plant life-traits, and an additional, eleventh category (11) connected with the conservation of the objects: establishment of conservation and management strategies.

Based on the analysis of the papers selected, the objects characteristic for the agricultural landscape were established as the objects of studies: forest patches, grasslands, mid-field islets, road verges, heathland and ponds. The summary table presents (Appendix 1) detailed information about the analyzed articles. 


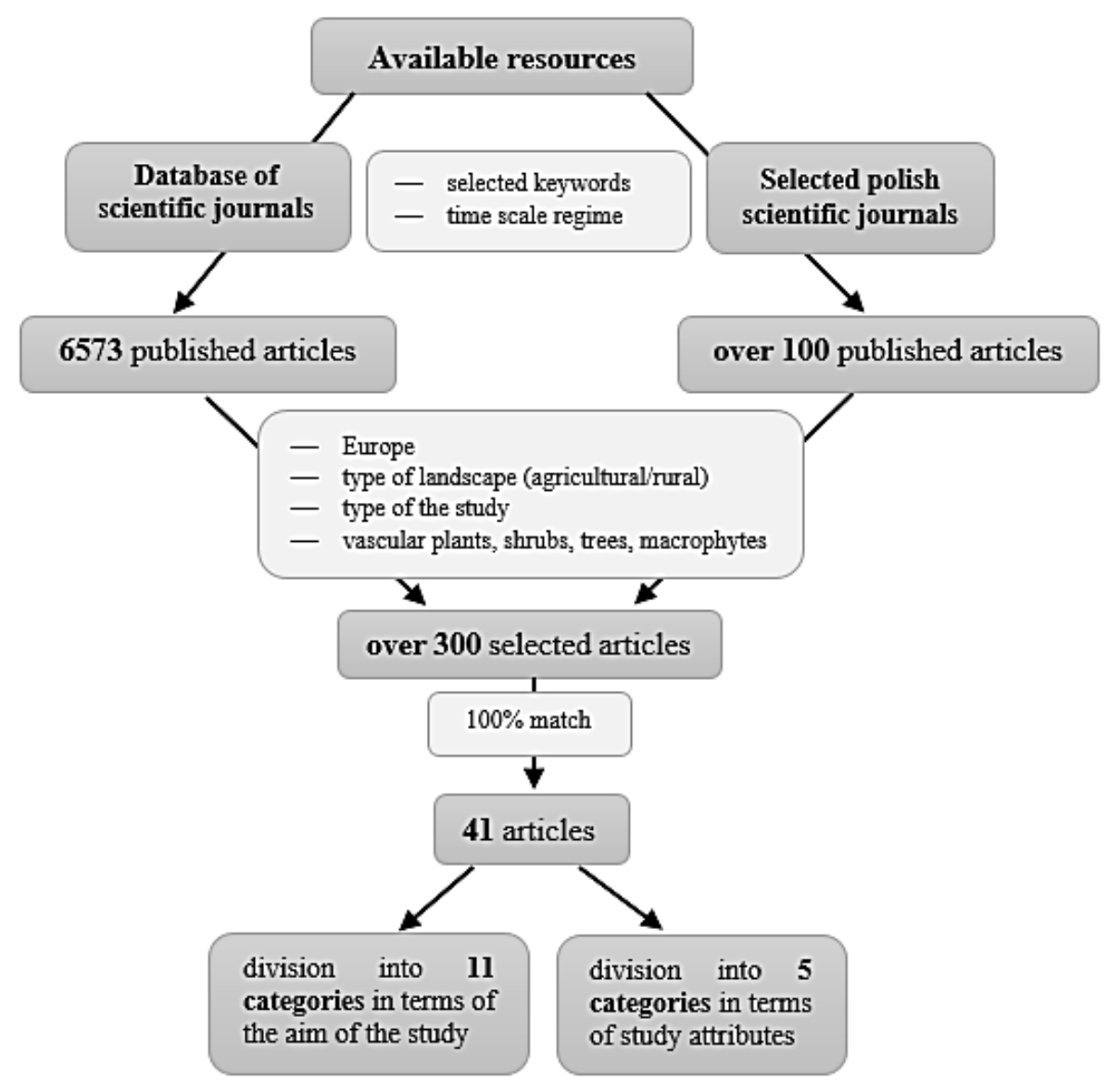

Figure 1. Methodology scheme

\section{Results}

Entering various configurations of the selected keywords into the literature databases as chosen resulted in finding the total of 6673 papers published in years 1997-2018. Following that, 41 papers which fulfilled the criteria as presented in "Methods" section were selected. The selected papers were published in 16 scientific journals. The leading ones were: Journal of Vegetation Science and Biological Conservation (14.6\%), whereas Agriculture, Biodiversity and Conservation, Ecography, Ecosystems and Environment, Forest Ecology and Managment as well as Landscape Ecology published three papers each $(7.3 \%)$ (Appendix 2).

\section{Study design and species data}

In all analysed studies the most common method of acquiring information on the species composition of objects studied were field studies $(95.1 \%)$ carried out mostly in the vegetation period of one year $(61.0 \%)$. Eight research teams were collecting data on plants over the period of 2 years $(19.5 \%)$, however, some papers did not contain any information on the length of the studies carried out (16.7\%). The analysis of 2 out of 41 papers selected was based on the existing data: survey carried out by the Provincial Government of Drenthe and The Lincolnshire data set (Grashof-Bokdam, 1997; Verheyen et al., 2004, respectively). Some of the research as presented in the studies 
was carried out in laboratories, where also the composition and the properties of soil extracted from a studied object were analysed (38.8\%) (Appendix 1).

The subject of studies in the Western European countries were very diversified objects forming part of the agricultural landscape: grassland patches (20), forest patches (20), midfield islets (5), ponds (4), road verges (3) and heathlands (1) (Figure 2). Some of the studies analysed referred to more than one object (14.6\%).

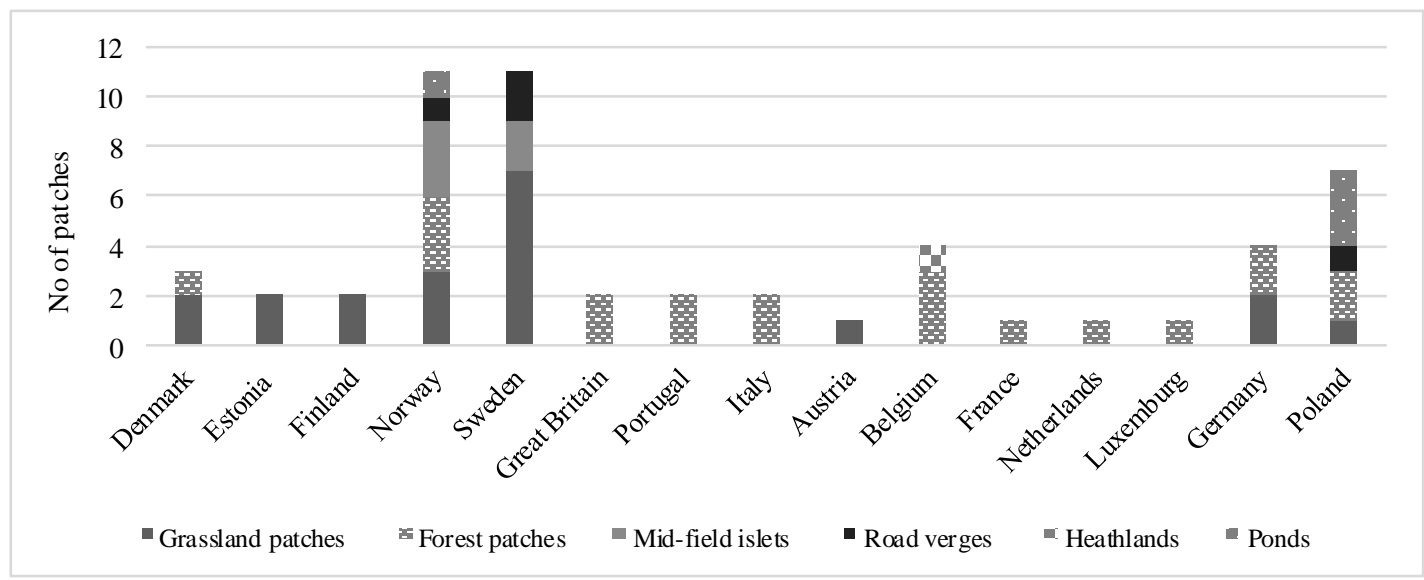

Figure 2. Type and number of the objects studied in 15 European countries

\section{Aim of the studies}

The first basic criteria determining the choice of papers for further analysis was the aim of the study (Table 2). The topic of all foreign papers as analysed was the determination of the influence of the fragmentation of the habitats and the landscape on the plant species richness of the objects typical for the agricultural landscape. In large part of the studies this thematic scope was defined as the main aim of the study (18 papers constituting 43.9\%). In 14 papers, apart from determining the influence of the fragmentation of the habitats and the landscape on the plant species richness, the features of the objects of study (size, shape) were the main factor which motivated the authors to take up and to perform the research (34.1\%). Habitat-related factors, the quality and the features of the landscape as well as isolation effect $(31.7 \%, 22.0 \%$, and $19.5 \%$, respectively) constituted also a very important aspect influencing the phytodiveristy of the object studied in the scientific papers as analysed. A presentation of the fragmentation of the agricultural landscape over years and the historical context of the development of the landscape was the main aim for 8 research teams $(19.5 \%)$. Two out of all the studies analysed focused on determining the plant species richness in two zones of a given object: ecotone as a transition area and the interior (4.9\%). In few papers it was verified whether plant life-traits, their dispersive abilities and an abandonment had an actual impact on species composition $(2.4 \%, 4.9 \%$, and $2.4 \%$, respectively). The main aim of three studies was a presentation of conservation and management strategy within study points subject to analysis (7.3\%). In almost half of the studies $(51.2 \%)$, the authors presented the rationale for conservation of given objects, even though this were not the main aims of the studies. The following table contains a summary and a presentation of the main aims of the studies analysed. 
Table 2. Main features of the analysed studies

\begin{tabular}{|c|c|}
\hline Study attributes & References \\
\hline Fragmentation & $\begin{array}{l}\text { Grashof-Bokdam, 1997; Jacquemyn et al., 2001; } \\
\text { Dumortier et al., 2002; Kolb and Diekmann, 2004; 2005, } \\
\text { Verheyen et al., 2004; Piessens et al., 2005; Bratli et al., } \\
\text { 2006; Cousins 2006, Helm et al., 2006; Johansson et al. } \\
\text { 2008; Reitalu et al., 2009; Hamre et al., 2010; Gazol et } \\
\text { al., 2012; Öckinger et al., 2012; Lindborg et al., 2014; } \\
\text { Huber et al., 2017; Buffa et al., } 2018\end{array}$ \\
\hline Interior and edge & Grashof-Bokdam, 1997; Vallet et al., 2010 \\
\hline Isolation & $\begin{array}{l}\text { Bruun, 2000a, 2000b; Graae, 2000; Krauss et al., 2004; } \\
\text { Petit et al., 2004; Cousins, 2006, Cousins et al., 2007; } \\
\text { Zulka et al., } 2014\end{array}$ \\
\hline Patch attributes & $\begin{array}{l}\text { Bruun 2000b; Honnay et al., 1999; Graae, 2000; } \\
\text { Jacquemyn et al., 2001; Krauss et al., 2004; Petit et al., } \\
\text { 2004; Orłowski and Nowak, 2005, Økland et al., 2006, } \\
\text { Cousins et al., 2007; Raatikainen et al., 2009; Lomba et } \\
\text { al., 2011; Bosiacka and Pieńkowski, 2012; Lomba et al., } \\
\text { 2013; Zulka et al., } 2014\end{array}$ \\
\hline Habitat conditions & $\begin{array}{l}\text { Bruun, 2000a; Kolb and Diekmann, 2004; Hérault and } \\
\text { Honnay, 2005; Cousins, 2006; Löbel et al., 2006; Økland } \\
\text { et al., 2006; Raatikainen et al., 2009; Hamre et al., 2010; } \\
\text { De Sanctis et al., 2010; Gazol et al., 2012; Zulka et al., } \\
\text { 2014; Koszelnik-Leszek et al., 2015; Huber et al., } 2017\end{array}$ \\
\hline Landscape structure & $\begin{array}{l}\text { Honnay et al., 1999; Krauss et al., 2004; Petit et al., } \\
\text { 2004; Hérault and Honnay, 2005; Cousins, 2006; Löbel } \\
\text { et al., 2006; Økland et al., 2006; Mathias, 2007; Gazol et } \\
\text { al., } 2012\end{array}$ \\
\hline Dispersion & Graae, 2000, Orłowski and Nowak, 2005 \\
\hline $\begin{array}{l}\text { Fragmentation in time (historical } \\
\text { context) }\end{array}$ & $\begin{array}{l}\text { Jacquemyn et al., 2001; Luoto et al., 2003; Bosiacka and } \\
\text { Pieńkowski, 2004; Cousins, 2006, Cousins et al., 2007, } \\
\text { Johansson et al., 2008; Reitalu et al., 2009; Gamrat et al., } \\
2017\end{array}$ \\
\hline Abandonment & Luoto et al., 2003 \\
\hline Plant life-traits & Hérault and Honnay, 2005 \\
\hline $\begin{array}{l}\text { Establishment of conservation and } \\
\text { management strategies }\end{array}$ & Orłowski and Nowak, 2005, Lomba et al., 2011, 2013 \\
\hline
\end{tabular}

\section{Data analysis}

Species richness is considered an important measure used for determining biological diversity of a given area. This is mostly due to the simplicity of measuring it in the case of vascular plants. The appraisal and the monitoring of biodiversity may be conducted by reference to various scales: local, landscape, and the macroscale (Ferretti et al., 2006).

The majority of the analysed Western European studies, employed landscape scale (43.9\%), which takes into account the influence of matrix on plant species richness. 
A little less, $36.6 \%$ of studies used local scale as a reference point of their analysis. The least common was macroscale category (19.5\%), which takes into account among others climate change aspect, which is line with the overall trend in landscape studies around the world (Opdam and Wascher, 2004; Engler and Guisan, 2009; Keshtkar and Voigt, 2016).

The diversity of species is a measure which takes into account the total species richness and their abundance/density. Patch level approach uses for measuring species richness an $\alpha$ diversity index defining the total number of species in a given area $-S$. It depends on the area of a given space and the size of a sample. However, in focal patch approach a diversity index $-\gamma$, which constitutes a total of variety - $\alpha$ (Whittaker, 1972; Sienkiewicz, 2010) is applied. The most common indices for determining this measure are diversity $(H)$ and evenness indices, Shannon's $(E)$ (Shannon, 1948) and Simpson's (D) (Simpson, 1949) (Gotelli and Chao, 2013). From among 41 European, Englishlanguage studies, only 4 used more detailed diversity indices - $\alpha$ or $\gamma$. In the remaining 37 papers species richness was defined as the total number of species established in a given area during field studies, through making lists of species and taking phytosociological pictures.

In the majority of papers analysed for the purpose of presenting the location of study points and their area, defining the level of their isolation and the distance between them as well as the fragmentation of given areas over time (90.2\%), Geographical Information System (GIS) was used (e.g. Honnay et al., 1999; Dumortier et al., 2002; Bosiacka and Pieńkowski, 2012; Buffa et al., 2018). Most commonly used software for this purpose was ArcGIS package (59.5\%) (e.g. Økland et al., 2006). One of the papers used Fragstats (2.4\%) (De Sanctis et al., 2010). In a small part of given papers there was not mentioned the name of the software used (10.8\%) (e.g. Bruun, 2000b; Raatikainen et al., 2009).

Inclusion of statistical analysis into the research might seem necessary for the purpose of complex presentation of links between a number of factors connected with habitats, the landscape or the environment and the plant species richness. However, in small part of performed studies it was not included (7,3\%) (Bosiacka and Pieńkowski, 2004; Koszelnik-Leszek et al., 2015; Gamrat et al., 2017). Studies, which applied statistical analysis in their studies, determined the connection between various factors influencing the plant species richness of the selected objects of study.

\section{Variables involved in research}

An analysis of the selected studies showed diversity in the selection of factors which may influence the plant species richness (Figure 3). The most commonly studied factor was the area of a given object $(63.4 \%)$ (e.g. Grashof-Bokdam, 1997; Kolb and Diekmann, 2004; Mathias et al., 2007; Öckinger et al., 2012; Koszelnik-Leszek et al., 2015; Huber et al., 2017). The most important group which determined the scope and the performance of the studies were ,landscape metrics" group components (38.5\%), with the level of isolation being the most commonly determined value for this category (28.3\%) (Graae, 2000; Dumortier et al., 2002; Piessens et al., 2005; Bosiacka and Pieńkowski, 2012). The least commonly established were connections between the plant-related metrics and the species richness (9.6\%) (e.g. Brunn, 2000a; Kolb and Diekmann, 2005; Lindborg et al., 2014). 


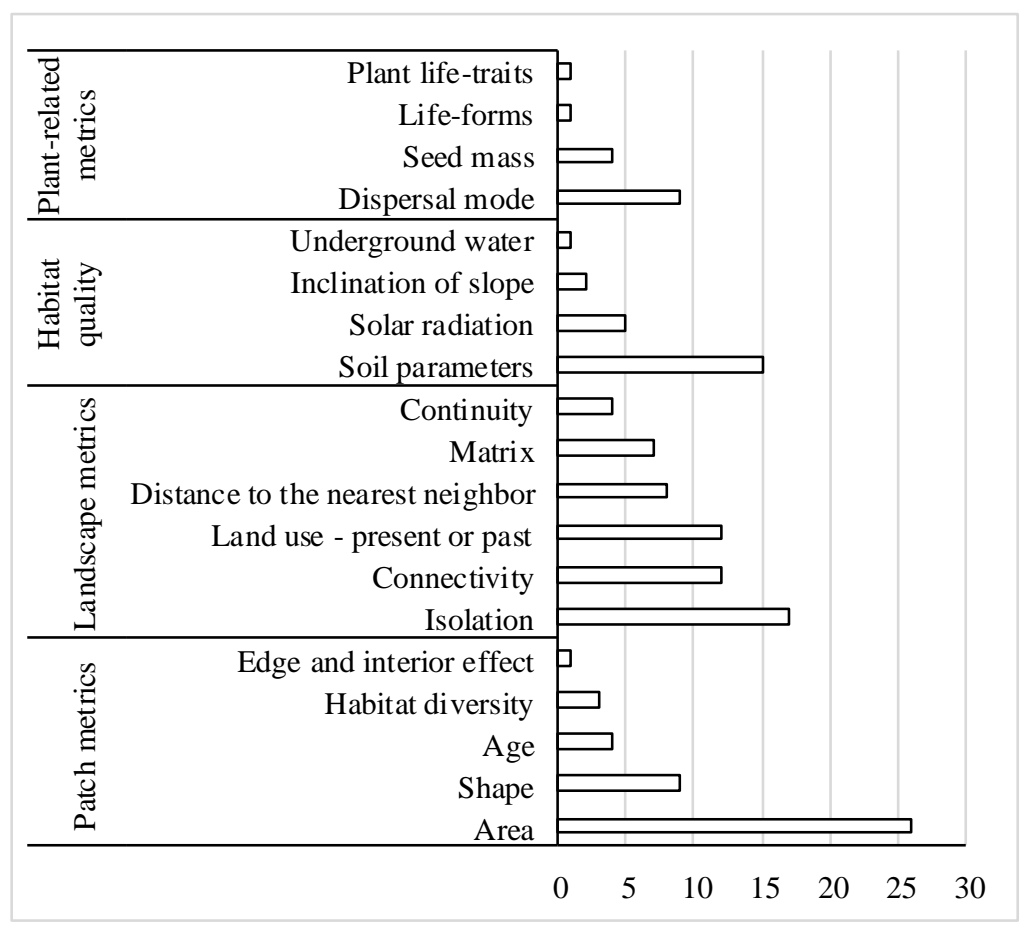

Figure 3. Variables involved in research divided into 4 categories

\section{Factors affecting plant species richness}

All the papers included in this analysis considered more than one factor affecting plant species richness. The influence of these factors was categorized for each type of the object studied as: positive, negative and no relevance.

\section{Grassland patches}

In the majority of the studies analyzed it was established that the greatest positive influence on plant species richness in grassland patches had the current area of the object (40.0\%) (Figure 4) (e.g. Krauss et al., 2004; Cousins et al., 2007; Raatikainen et al., 2009). It was concluded that an increase of an area occupied leads to an increase of a number of plant species present there. The way these objects are used (mowing or animal grazing) (e.g. Luoto et al., 2003; Reitalu et al., 2009; Hamre et al., 2010). and the diversity of habitats also have a positive impact (e.g. Mathias et al., 2007) $(25.0 \%$, $20.0 \%$, respectively).

The largest negative impact on species richness may be attributed to objects' isolation (30.0\%) (e.g. Raatikainen et al., 2009; Reitalu et al., 2009; which impairs dispersive abilities of species, forcing them to migrate through hostile matrix. Also abandonment of the grassland patches through a withdrawal of any plant care procedures had a negative impact (15.0\%) (e.g. Reitalu et al., 2009; Gazol et al., 2012). The analysis of the papers allowed also for determining the factors, which according to the researchers, did not affect species richness. Continuity, current connectivity, landscape history and land-use were considered factors whose values and scope have no impact on plant species richness (10.0\%, respectively) (e.g. Johansson et al., 2012). 


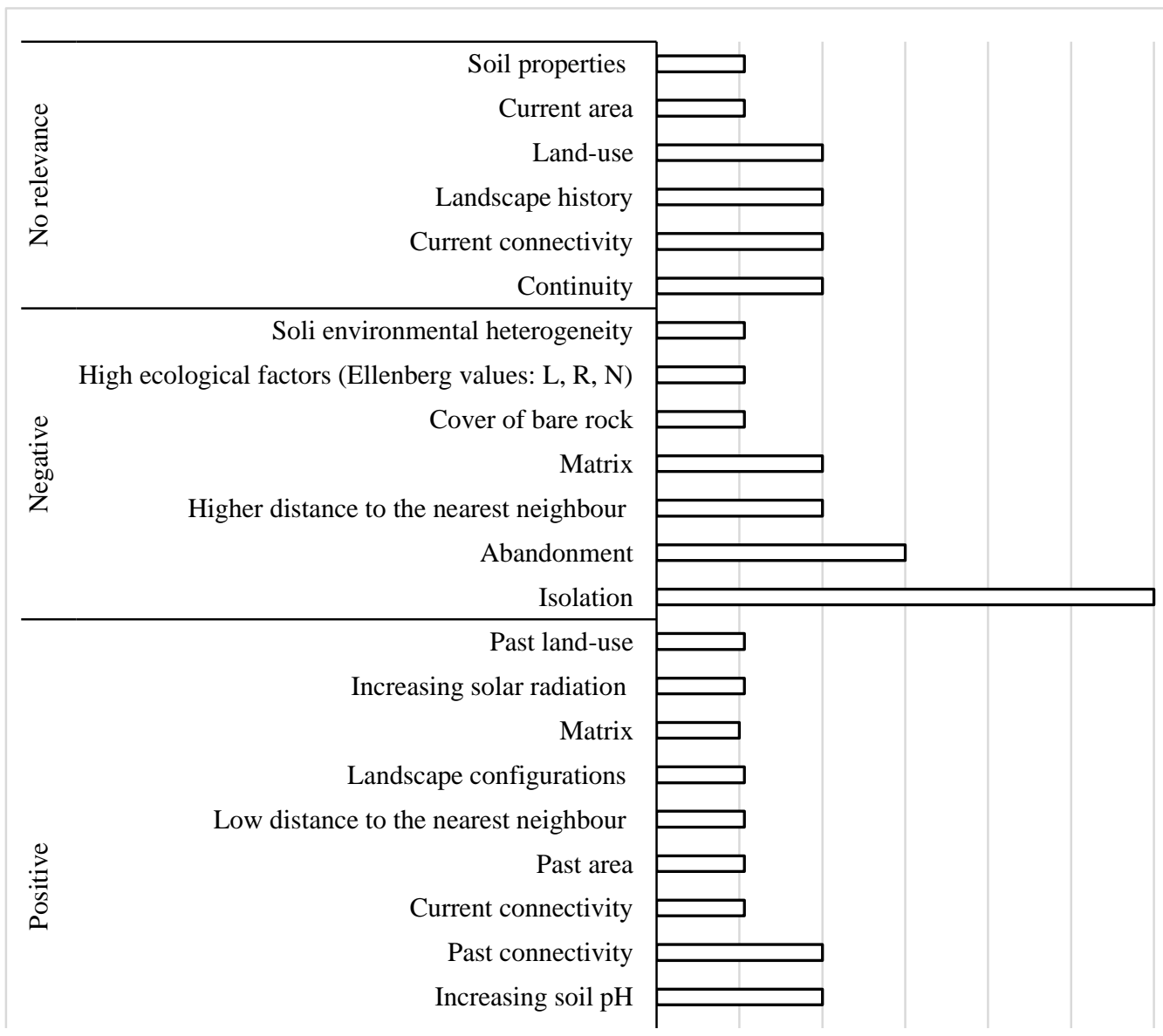

Figure 4. Influence of variables involved in research divided into 3 categories: positive, negative and not affecting plant species richness in grassland patches $(L-$ light value, $R-$ reaction of soil value, $N$ - nitrogen value)

\section{Forest patches}

In the case of the forest patches as studied, similarly as in the case of grassland patches, the largest positive influence was attributed by the scientists to their current area (55.0\%) (Honnay et al., 1999; Jacquemyn et al., 2001; Verheyen et al., 2004; Kolb and Diekmann, 2004; Buffa et al., 2018). An exception was three studies (15.0\%) (Lomba et al., 2011, 2013; Koszelnik-Leszek et al., 2015) in which it was established that there was no significant connection between species richness and the size of objects. One of the factors which were considered favorable for an increase of species richness was also current connectivity - it was concluded that plant species were more common in well-connected patches (Grashof-Bokdam, 1997; Petit et al., 2004; Verheyen et al., 2004; Hérault and Honnay, 2005; Kolb and Diekman, 2005) (25.0\%) (Figure 5).

The biggest negative impact was attributed to isolation (25.0\%) (e.g. Graae, 2000; Kolb and Diekmann, 2004), whereas ecological values were considered nonaffecting in $10.0 \%$ of studies on plant species richness of the selected landscape objects (e.g. Petit et al., 2004). 


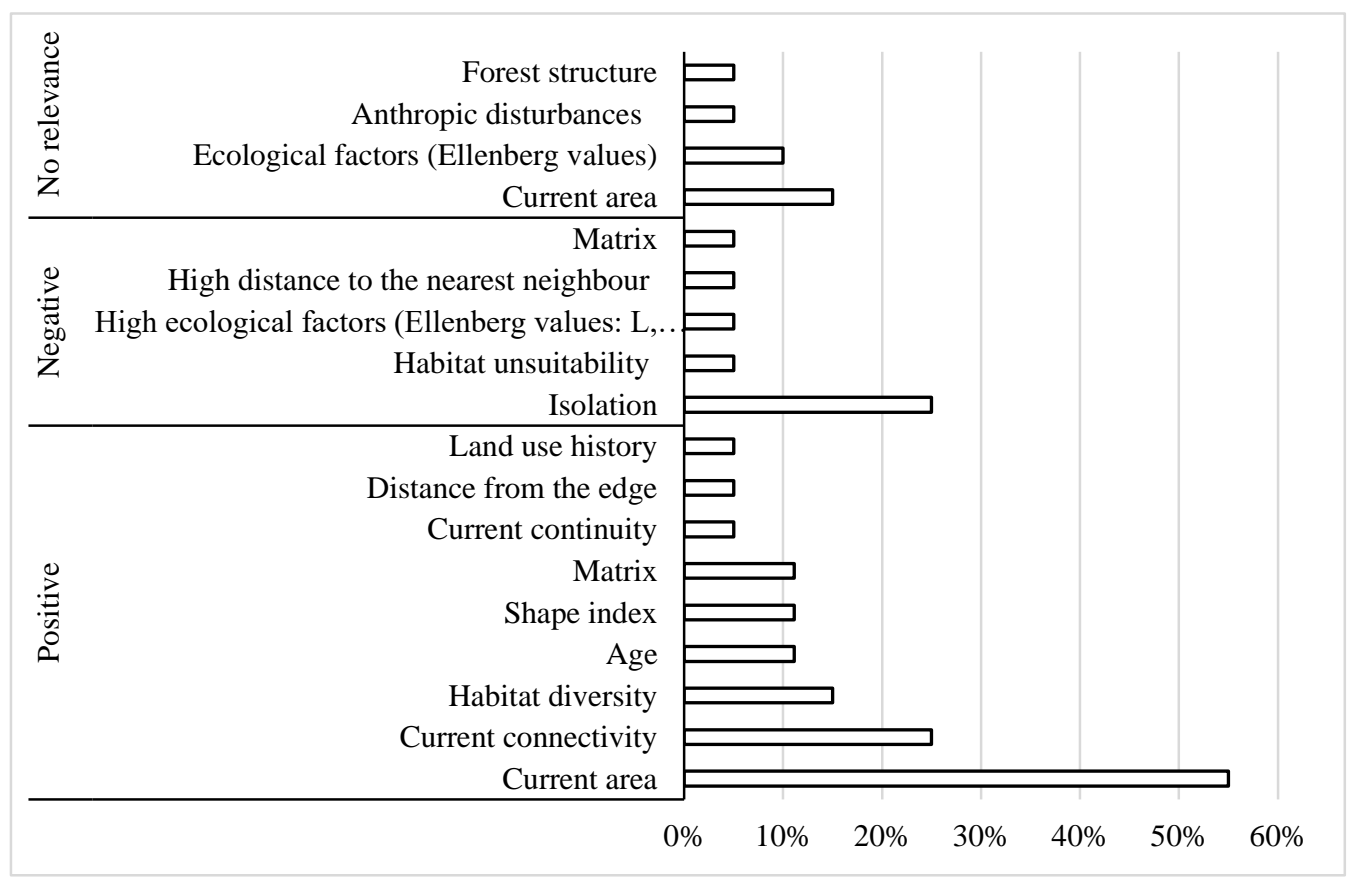

Figure 5. Influence of variables involved in research divided into 3 categories: positive, negative and not affecting plant species richness in forest patches ( $L$-light value, $R$ - reaction of soil value, $N$ - nitrogen value)

\section{Midfield islets}

Half of the research teams whose studies comprised midfield islets, considered that the appropriate management of these objects (Cousins, 2006) and their current area (Cousins, 2006) had a positive impact on plant species richness (Figure 6). Habitat diversity of the patches also had positive effect on phytodiversity of these areas $(33.3 \%)$ (Bratli et al., 2006).

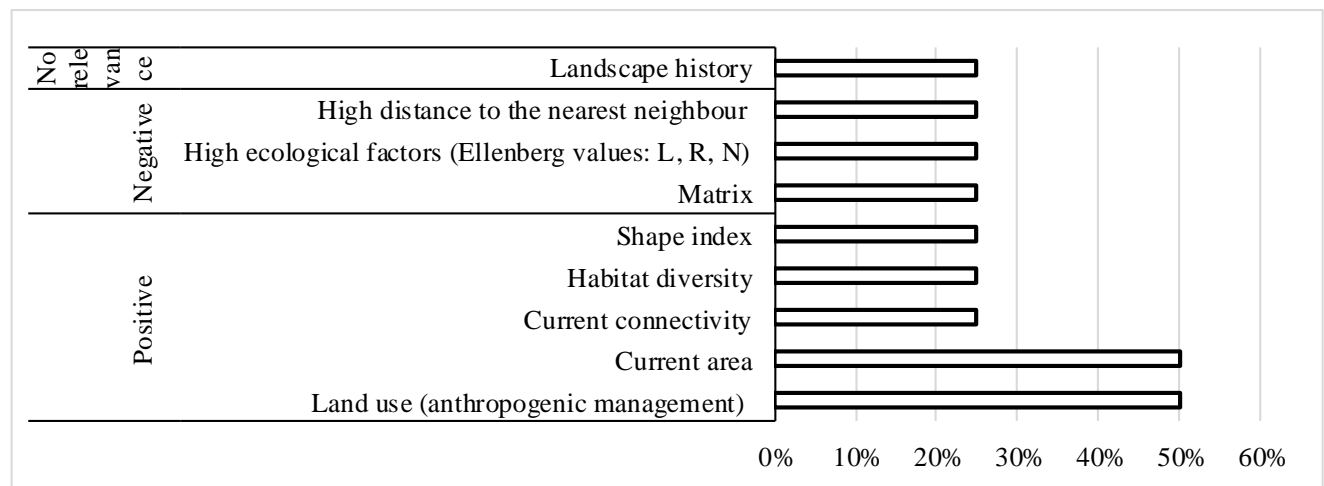

Figure 6. Influence of variables involved in research divided into 3 categories: positive, negative and not affecting plant species richness in midfield islets $(L$-light value, $R$ - reaction of soil value, $N$ - nitrogen value) 
Negative factors were considered to be a long distance to the closest neighbour (Lindborg et al., 2014), matrix and high ecological factors (Økland et al., 2006). Studies performed by Cousins (2006) showed that landscape history is irrelevant for plant species richness.

\section{Road verges}

Road verges constituting a mandatory component of every agricultural landscape are positively affected by purposeful human activity - plant-care activities within road verges (e.g. mowing) (50.0\%) (Cousins, 2006; Økland et al., 2006) (Figure 7). An important environmental factor which has a positive influence on plant communities is habitat diversity (Gamrat et al., 2017), shape index (Økland et al., 2006), current area (Økland et al., 2006) and the landscape aspect - current connectivity (Cousins, 2006) (25.0\% respectively).

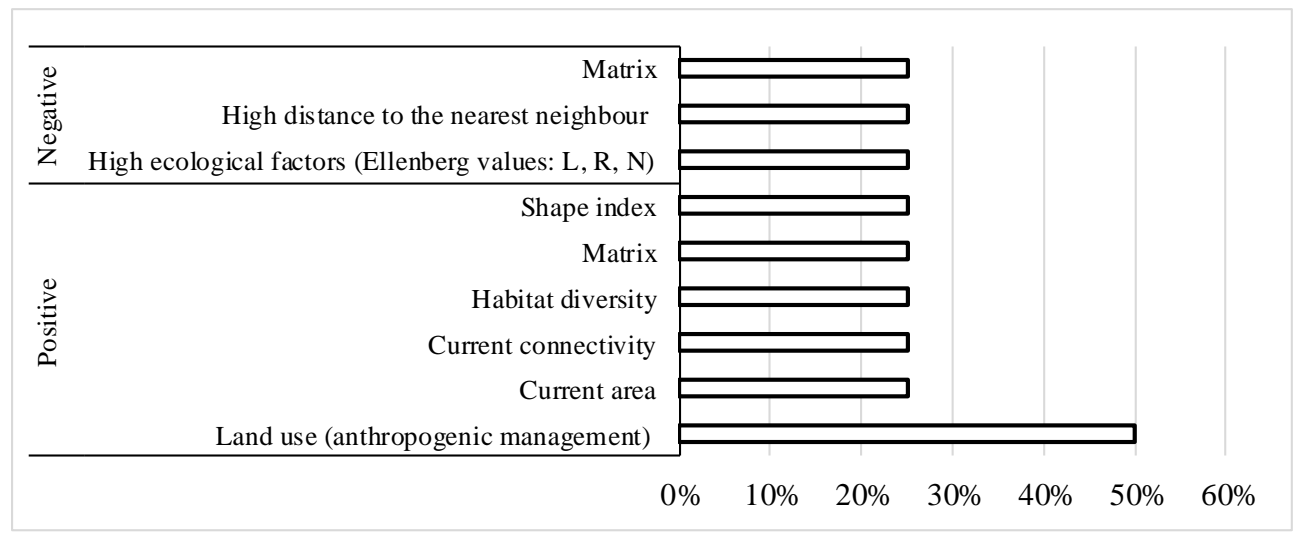

Figure 7. Influence of variables involved in research divided into 2 categories: positive and negative on plant species richness in road verges ( $L$-light value, $R$-reaction of soil value, $N-$ nitrogen value)

Based on the English-language literature related to road verges, three factors which affect negatively plant species diversity were determined: long distance to the nearest neighbour (Lindborg et al., 2014), which results from the insulation of these objects, high ecological values and the matrix (Økland et al., 2006). Nonaffecting factors were not identified.

\section{Heathlands}

Literature on heathlands (Piessens et al., 2005) is sporadic. It was established though that isolation has a negative impact on plant species richness. It was also concluded that current area of the object studied does not affect its phytodiversity.

\section{Ponds}

Out of the 41 papers as selected (based on the methodological criteria applied), four research teams included ponds in their studies (Appendix 1). It was determined that floristic diversity is positively affected by the current area and the shape of the objects (Økland et al., 2006; Bosiacka and Pieńkowski, 2012). The matrix (Gamrat et al., 2017)), 
high ecological values (Økland et al., 2006) and isolation (Bosiacka and Pieńkowski, 2012) were considered to be negative factors (25.0\%, respectively) (Figure 8).

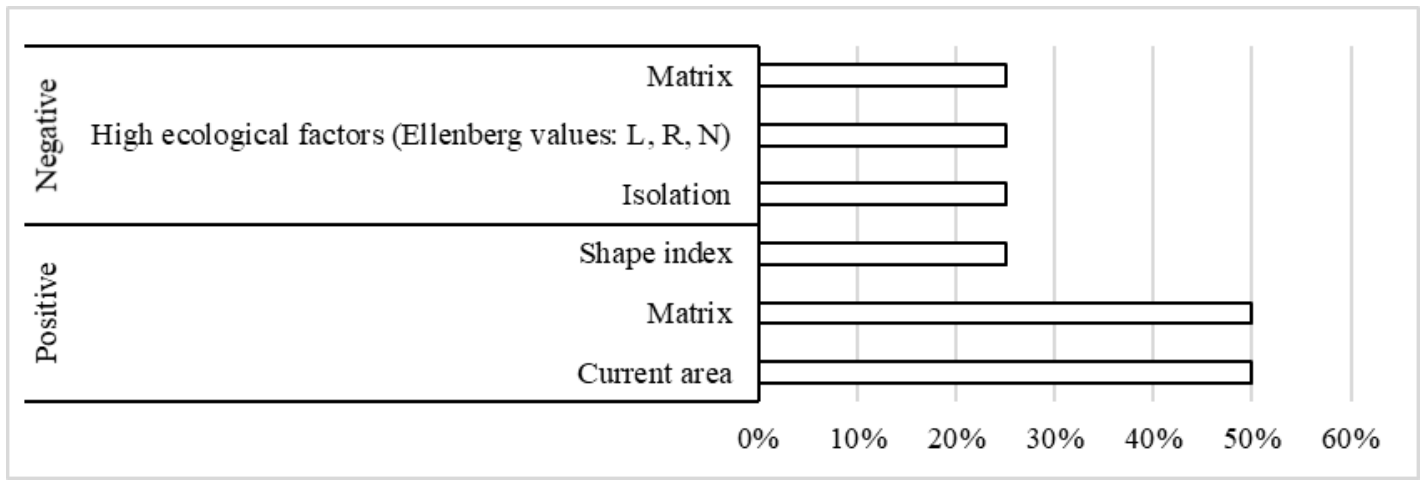

Figure 8. Influence of variables involved in research divided into 2 categories: positive and negative on plant species richness in ponds

In the majority $(75.0 \%)$, ponds were examined in the area of the north-western part of Poland, which may be due to the fact that these are objects characteristic of the young glacial landscape (Bosiacka and Pieńkowski, 2004).

\section{Discussion}

Based on the methodological criteria selected attempts were made to select a group of scientific papers. In the given literature, the methods of evaluating an impact of fragmentation on plant species richness in different spatial objects characteristic for the agricultural landscape in 15 Western European countries were analyzed. The categorization of scientific papers proposed in the methodological part allowed to compare the applied research methodologies and their analysis, as well as to determine the impact of fragmentation of the agricultural landscape on the species richness of the studied objects.

The meta-analysis of scientific articles is undertaken in order to systematize applied research methods in a given field. In this paper, the authors focused on landscape studies taking into account the species richness of plants that can be shaped by many spatial factors. Aim of this paper was to analyze the main assumption of The Theory of Island Biogeography, whose main indicators are the isolation and area of a given object. International research in this subject does not explicitly indicate the possibility of using this theory in relation to various spatial objects in the agricultural landscape. An additional difficulty, indicated by Fardila et al. (2017), is an insufficient number of studies published in a language other than English, included in the international literature of the subject. Therefore, the presented paper presents, in addition to Englishlanguage works, the results of research by Polish scientists.

Comparison of all selected articles, indicates that the main types of objects in landscape studies are grasslands (48.8\%) and forest patches (48.8\%). This differs from the position of Fardila et al. (2017), who reviewed the research on the impact of fragmentation on the species richness of all biotic elements around the world and found that the main subject of researches were forest patches. Less attention was focused on the remaining types of objects. However, it was submitted that the research on 
fragmentation should be carried out within various habitat types, because the problem of biodiversity decline affects all ecosystems, not only forest ones (Fardila et al., 2017). Small habitats, such as road verges, shading trees or mid-field islets, are also an important element of the agricultural landscape, raising its value, constituting a refugium and being a source of seed dispersal (Lindborg et al., 2014).

The majority of floral studies of the objects situated in the fragmented agricultural landscape as analyzed was performed in Scandinavian countries - Sweden, Norway, Denmark or Finland (44.4\%). From among all studies related to grassland, it was the most common object of studies in these countries (73.4\%). It may result from the fact that in the last century a decrease of these areas in Scandinavia by about $90 \%$ due to radical changes in their management has been noticed (Eriksson et al., 2002). This led to the need of defining and presenting the negative consequences of the landscape transformation (fragmentation). Biological value of grassland results among others from the fact that it is characterized by very high species density, which often amounts up to even $60 * \mathrm{~m}-{ }^{2}$. Furthermore, many species inhabiting grassland are present also in other habitats, constituting their component for example: heathland, road verges, forest patches or small midfield islets surrounded by farm land (Eriksson et al., 2002). It is considered that grassland patches constitute the so called hotspots of diversity being a key factor influencing an increase in biodiversity of the agricultural landscape (Hamre et al., 2010; Habel et al., 2013).

What is worth noting Polish research on grasslands differs from research conducted in other European countries. Above all, there are relatively few of them, and those that are conducted, methodically differ from the European patterns. However, this proportion should change in the coming years, at it is believed that grassland is more prone to degradation due to its spatial location, which allows for an easy change to the way it is used (Fardila et al., 2017). Similarly, as in the case of studies in the remaining European countries, there are few studies performed on small objects with high ecological values such as road verges. As in the case of research in other European countries, in Poland, observations on small but valuable natural objects such as road verges were rarely carried out. The creation of new, even small environmental islands, contributes to inhibiting the extinction of species (Bennet and Saunders, 2011).

Studies on fragmentation of the landscape and habitats are carried out all over the world and involve analyses of flora and fauna. Researchers try not only to define biodiversity of a given area, but also pose a question: how it should be protected and how to manage given objects to be able to prevent homeostasis of ecosystems. Heinken and Weber (2013) claim that fragmentation does not affect in the same way all plant communities and habitats, which makes it more difficult to present or develop one general conservation plan for all ecosystems. Better understanding of fragmentation, achieved due to specialized and complex studies of this process, may help to develop a strategy of conservation of domestic and endangered plant species in isolated objects and identify those which are most susceptible to habitat loss.

Bennet and Saunders (2011) assigned a negative impact on species diversity in the process of habitat degradation to alien species invasion. They consider that proper control and management of objects may be the key importance for maintaining biocenotic balance. Moreover, they suggest that taking appropriate actions not only within isolated patches but also within landscape and macroscale. Additionally, it requires constant control of abiotic factors such as erosion, input of pollutants and anthropogenic pressure connected with recreation aspect. 
An analysis of literature allowed a presentation of different approaches to carrying out studies of one area by the same research teams, however with use of different methodology. It was particularly noticeable in the context of studies carried out on Öland island (Sweden) (Löbel et al., 2006; Johansson et al., 2008; Reitalu et al., 2009). Each of the papers presented an influence of a number of different factors (Appendix 1) which may contribute to plant species richness of selected grassland. The selection of a particular factor affected obtained results, which in turn had an influence on the way biodiversity of a given object was perceived. Löbel et al. (2006) concluded that higher $\mathrm{pH}$ has a positive impact on phytodiversity of the objects studied. Johansson et al. (2008) considered historical aspects of the use of land to be a positive factor, whereas Reitalu et al. (2009) defined appropriate management of grassland as a positive contributor to plant species richness.

Sjaelland island (Denmark) was subject to studies twice (Brunn, 2000a, 2000b), with the aim being the establishment of the influence of isolation and area diversity of the objects on plant species richness. In one of the studies (Brunn, 2000) it was verified additionally whether there is a link between abundance of species and the weight of seeds, and in the second study the author presented forecasts of potential richness and deficit of species (Brunn, 2000a) on the island subject to studies.

Another example of a diversified approach to the selection of factors contributing to biodiversity with respect to the same objects, are studies performed by teams of Lomba et al. (2011, 2013) (Appendix 1). In both studies, different research methodologies with different main assumptions were used. One of the studies focused on presenting forest type (dominant tree species), forest patch spatial attributes (patch area and shape index), and measures of forest management and structure (Lomba et al., 2011) as factors which may potentially affect phytodiveristy. In the second one (Lomba et al., 2013) speciesarea relationship (SARs) was established. SARs is one of the oldest and the best documented research methods, which describes an increase of species richness to area relationship. It may have different forms and it may be explained by different mechanisms (Tessel et al., 2018). However, a selection of factors which may affect phytodiversity made no difference to the results obtained as in both cases it was established that there is no link between current area of forest patches and floristic diversity. Furthermore, in both studies it was established that there is a positive correlation between an increase of species richness and an increase in natural character of forest patches. Whereas shape index, as a physical factor shaping ecotone habitats (Lomba et al., 2011), turned out to be a positive contributor to biodiversity of the whole patches. It is considered that the diversity of the given ecotone with respect to habitats increases with the increase of diversity of the shape of a given object.

Selected scientific articles (especially English-language ones) are characterized by complexity in terms of the analysis of the available subject literature and applied research methodologies. They take into account many factors that can shape the species richness of plants, and check the potential correlations between them, through the use of statistical analysis. In turn, in the research of Polish scientists, the undisputed asset is the detailed field research (phytosociological) related to the acquisition of a large amount of data in the form of phytosociological images and often associated environmental variables. The share of species in the phytosociological picture is usually given in the six-stage combined quantitative scale - coverage (Zarzycki, 2009) proposed by Braun-Blanquet. 
The meta-analysis points to the need for scientists to protect the environmental islands as valuable spatial objects. It is recommended to protect larger patches, where there is a low risk of extinction of species characteristic for a given habitat (Krauss et al., 2004; Mathias et al., 2007), or appropriate management of grassland patches (mowing and grazing) (Gazol et al., 2012; Zulka et al., 2014; Huber et al., 2017). In addition, Hamre et al. (2010) also note the need to include historical maps of the studied areas, as they are a useful tool to understand landscape changes over the years, including changes in the spread of plant species and extinction debt. Extinction debt, in ecological terms, is considered to be populations of existing species that are likely to perish as a result of changes in the environment: habitat destruction, climate change or invasion of alien species (Kuussaari et al., 2009).

\section{Summary}

The analysis of selected available literature allowed to determine a number of factors affecting the species richness of plants, such as habitat diversity, connectivity, the shape of the object or its management. The conducted study indicates that usually the greatest positive role is assigned to area of a given patch (over $95.0 \%$ of the analyzed works including this factor in the research). It allows to conclude that increasing area of habitats and the general number of spatial objects in the landscape may limit the impact of the negative effects of the fragmentation process, which will additionally improve the connectivity. Another analyzed factor affecting the species richness of plants, according to The Theory of Island Biogeography (MacArthur and Wilson, 1967) is isolation. Its negative effect on plant species richness was observed in more than $70.0 \%$ of the papers emphasizing this factor in research. The review of landscape research confirmed the thesis that the area and isolation cannot be unambiguously determined to shape biodiversity in the patches. The reason for this may be the diversity of the examined objects, the differentness in the statistical analysis, the insufficient number of field studies, as well as the location of objects in space (geographical aspect).

Fragmentation of the landscape, especially agricultural, is assigned to the negative significance in relation to the preservation of species diversity. As a result of this process, the habitats are reduced, creating isolated patches. They are also often separated by surfaces used by humans, or are adjacent to communities of synanthropic species, adapted to live in a strongly transformed environment. Fragmentation is most often the result of human activity (Kuussaari et al., 2009), directed at the development of agriculture, therefore the task of society, scientists and territorial authorities is to create protection strategies and conduct activities that minimize the negative impact of this process. Not only proper management, but also the creation of new, ever larger objects that are a refuge of biodiversity, can help maintain the homeostasis of endangered ecosystems.

It is suggested to continue, increase the number and refine research into the impact of fragmentation on biodiversity in order to better understand this phenomenon and its effects on the landscape and other elements of the environment. It would be necessary to introduce broader statistical analyzes of biodiversity indicators using, for example, the Shannon and Simpson index for comprehensive research and inference. It should be emphasized that in landscape studies, it is necessary to use geographical information systems (GIS) as a spatial analysis tool to understand and explain the impact of fragmentation on biodiversity. 


\section{REFERENCES}

[1] Aavik, T., Lira, J. (2010): Quantifying the effect of organic farming, field boundary type and landscape structure on the vegetation of field boundaries - Agric. Ecosyst. Environ. 135: $178-186$.

[2] Allan, E., Manning, P., Alt, F., Binkenstein, J., Blaser, S., Bluthgen, N., Bohm, S., Grassein, F., Holzel, L., Klaus, V. H., Kleinbecker, T., Morris, E. K., Oelmann, Y., Prati, D., Renner, S. C., Rillig, M. S., Schaefer, M., Schloter, M., Schmitt, B., Schoning I., Schrumpf M., Solly E., Soraku E., Steckel J., Steffen-Dewenter I., Stempfhuber, B., Tschapka, M., Weiner, C. N., Weisser, W. W., Werner, M., Westphal, C., Wilcke, W., Fischer, M. (2015): Land use intensification alters ecosystem multifunctionality via loss of biodiversity and changes to functional composition - Ecol. Lett. 18: 834-843.

[3] Bennet, A. F., Saunders, D. A. (2011): Habitat fragmentation and landscape change. - In: Sodhi, N.S., Ehrlich, P.R. (eds.) Conservation biology for all. Oxford University Press, Oxford: 88-106.

[4] Bosiacka, B., and Pieńkowski, P. (2004): Analysis of pond transformations and evaluation of the natural values of midfield water bodies in central part of the Nowogard plain - Woda-Środowisko-Obszary wiejskie 4(2a): 335-349. (In Polish)

[5] Bosiacka, B., Pieńkowski, P. (2012): Do biogeographic parameters matter? Plant species richenss and distribution of in relations to area and isolation of ponds in NW Polish agricultural landscape - Hydrobiologia 689: 79-90.

[6] Bratli, H., Økland, T., Økland, R. H., Dramstad, W. E., Elven, R., Engan, G., Fjellstad, W., Heegaard, E., Pedersen, O., Solstad, H. (2006): Patterns of variation in vascular plant species richness and composition in SE Norwegian agricultural landscapes - Agric. Ecosyst. Environ. 114: 207-286.

[7] Bruun, H. H. (2000a): Patterns of species richness in dry grassland patches in an agricultural landscape - Ecography 23: 641-650.

[8] Bruun, H. H. (2000b): Deficit in community species richness as explained by area and isolation of sites - Divers. Distrib. 6: 129-135.

[9] Buffa G., del Vecchio, S., Fantinato, E., Milano, V. (2018): Local versus landscape-scale effects of anthropogenic land-use on forest species richness - Acta Oecol. 86: 49-56.

[10] Cangolo, L., Cabido, M., Valladares, G. (2006): Plant species richness in the Chaco Serrano Woodland from central Argentina: Ecological traits and habitat fragmentation effects - Biol. Conserv. 132(4): 510-519.

[11] Carrara, E., Arroyo-Rodríguez, V., Vega-Rivera, J. H., Schondube J.E., de Freitas S.M., Fahrig L. (2015): Impact of landscape composition and configuration on forest specialist and generalist bird species in the fragmented Lacandona rainforest, Mexico - Biol. Conserv. 184: 117-126.

[12] Chmielewski, T. J., Myga-Piątek, U., Solon, J. (2015): Typology of Poland's current landscapes - Przegląd Geograficzny 87(3): 377-408. (In Polish)

[13] Collins, C. D., Holt, R. D., Foster, B. L. (2009): Patch size effects on plant species decline in an experimentally fragmented landscape - Ecology 90(9): 2577-2588.

[14] Conradi, T., Kollmann, J. (2016): Species pools and environmental sorting control different aspects of plant diversity and functional trait composition in recovering grasslands - J. Ecol. 104: 1314-1325.

[15] Cook, W. M., Lane, K. T., Foster, B. L., Holt, R. D. (2002): Island theory, matrix effects and species richness patterns in habitat fragments - Ecol. Lett. 5: 619-623.

[16] Cousins, S. A. O. (2006): Plant species richness in midfield islets and road verges - the effect of landscape fragmentation - Biol. Conserv. 127: 500-509.

[17] Cousins, S. A. O., Ohlson H., Eriksson, O. (2007): Effects of historical and present fragmentation on plant species diversity in semi-natural grasslands in Swedish rural landscapes - Landscape Ecol. 22: 723-730. 
[18] Dauber, J., Bengtsson, J., Lenoir, L. (2006): Evaluating effects of habitat loss and landuse continuity on ant species richness in seminatural grassland remnants. -Conserv. Biol. 20(4): 1150-1160.

[19] De Sanctis, M., Alfo, M., Attorre, F., Francesconi, F., Bruno, F. (2010): Effects of habitat configuration and quality on species richness and distribution in fragmented forest patches near Rome - J. Veg. Sci. 21: 55-65.

[20] Debinski, D. M. (2006): Forest fragmentation and matrix effects: the matrix does matter J. Biogeogr. 33: 1791-1792.

[21] Debinski, D. M., Holt, R. D. (1999): A survey and overview of habitat fragmentation experiments - Conserv. Biol. 14(2): 342-343.

[22] Degórski, M. (2015): Polityka krajobrazowa w Polsce: wyzwania i szanse - Problemy Ekologii Krajobrazu 60: 13 - 25. (In Polish).

[23] DeLong, D. C. (1996): Defining biodiversity - Wildlife Soc. B. 24(4): 738.

[24] Dumortier, M., Butaye, J., Jacquemyn, H., Camp, van N., Lust, N., Hermy, M. (2002): Predicting vascular plants species richness of fragmented forests in agricultural landscapes in central Belgium - Forest. Ecol. Manag. 158: 85-102.

[25] Engler, R., Guisan, A. (2009): MigClim: Predicting plant distributionand dispersal in a changing climate - Divers. Distrib. 15: 590-601.

[26] Eriksson, O., Cousins, S. A. O., Bruun, H. H. (2002): Land-use history and fragmentation of traditionally managed grassland in Scandinavia - J. Veg. Sci. 13: 743-748.

[27] Ewers, R. M., Didham, R. K. (2006): Confounding factors in the detection of species responses to habitat fragmentation - Biol. Rev. 81: 117-142.

[28] Fardila, D., Kelly, L. T., Moore, J. L., McCarthy, M. A. (2017): A systematic rewiev reveals changes in where and how we have studied habitat loss and fragmentation over 20 years - Biol. Conserv. 212: 130-138.

[29] Ferretti, M., Bussotti, F., Camptella, G., Canullo, R., Chiarucci, A., Fabbio, G., Petriccione, B. (2006): Biodiversity - its assessment and importance in the Italian programme for the intensive monitoring of forest ecosystems CONECOFOR. - Ann. Ist. Sper. Selv. 30(2): 3-16.

[30] Fischer, J., Lindenmayer, D. B. (2007): Landscape modification and habitat fragmentation: a synthesis - Global Ecol. Biogeogr. 16: 265-280.

[31] Forman, R. T., Gordon, M. (1981): Patches and structural components for a landscape ecology. - Bioscience 31: 733-740.

[32] Fuentes-Montemayor, E., Goulson, D., Cavin, L., Wallace, J. M., Park, K. J. (2013): Fragmented woodlands in agricultural landscapes: The influence of woodland character and landscape context on bats and their insect prey - Agr. Ecosyst. Environ. 172: 6-15.

[33] Gamrat, R., Gałczyńska, M, Kupiec, M. (2017): Diversity of environmental islands in the agricultural landscape of Nowogard and Goleniowska Plains - Prace Komisji Krajobrazu Kulturowego 35: 29-42. (In Polish)

[34] Gazol, A., Tamme, R., Takkis, K., Kasari, L., Saar, L., Helm, A., Pärtel, M. (2012): Landscape and small-scale determinants of grassland species diversity: direct and indirect influences - Ecography 35: 944-951.

[35] Gotelli, N. J., Chao, A. (2013): Measuring and estimating species richness, species diversity, and biotic similarity from sampling data. - In: Levin, S. (ed.) Encyclopedia of Biodiversity. Academic Press, Waltham: 195-211.

[36] Graae, B. J. (2000): The effect of landscape fragmentation and forest continuity on forest floor species in two regions of Denmark - J. Veg. Sci. 11: 881-892.

[37] Grashof-Bokdam, C. (1997): Forest species in agricultural landscape in the Netherlands: Effect of habitat fragmentation - J. Veg. Sci. 8: 21-28.

[38] Habel, J. C., Dengler, J., Janišova, M., Török, P., Wellstein, C., Wiezik, M. (2013): European grassland ecosystems: threatened hotspots of biodiversity - Biodivers. Conserv. 22: $2131-2138$ 
[39] Haig, A. R., Matthes, U., Larson, D. W. (2000): Effects of natural habitat fragmentation on the species richness, diversity, and composition of cliff vegetation - Can. J. Botany. 78(6): 786-797.

[40] Hamre, L. N., Halvorsen, R., Edvardsen, A., Rydgren, K. (2010): Plant species richness, composition and habitat specificity in a Norwegian agricultural landscape. - Agric. Ecosyst. Environ. 138: 189-196.

[41] Hanski, I. (2005): Landscape fragmentation, biodiversity loss and the societal response. EMBO Rep. 6(5): 388-392.

[42] Heinken, T., Weber, E. (2013): Consequences of habitat fragmentation for plant species: Do we know enough? - Perspect. Plant Ecol. 15: 205-216.

[43] Helm, A., Hanski, I., Pärtel, M. (2006): Slow response of plant species richness to habitat loss and fragmentation - Ecol. Lett. 9: 72-77.

[44] Hérault, B., Honnay, O. (2005): The relative importance of local, regional and historical factors determining the distribution of plants in fragmented riverine forests: an emergent group approach - J. Biogeogr. 32: 2069-2081.

[45] Honnay, O., Hermy, M., Coppin, P. (1999): Effects of area, age and diversity of forest patches in Belgium on plant species richness, and implications for conservation and reforestation - Biol. Conserv. 87: 73-84.

[46] Huber, S., Huber, B., Stahl, S., Schmid, C., Reisch, C. (2017): Species diversity of remnant calcareous grasslands in south eastern Germany depends on litter cover and landscape structure - Acta Oecol. 83: 48-55.

[47] Ibáñez, I., Katz, D. S., Peltier, D., Wolf, S. M., Connor Barrie, B. T. (2014): Assessing the integrated effects of landscape fragmentation on plants and plant communities: the challenge of multiprocess-multiresponse dynamics - J. Ecol. 102: 882-895.

[48] Iida, S., Nakashizuka, T. (1995): Forest fragmentation and its effect on species diversity in sub-urban coppice forests in Japan - Forest Ecol. Manag. 73: 197-210.

[49] Irvinea, K. N., Devine-Wright, P., Payne, S. R.. Fuller, R. A., Painter, B., Gaston, K. J. (2009): Green space, soundscape and urban sustainability: an interdisciplinary, empirical study - Local Environment. 14(2): 155-172.

[50] Jacquemyn, H., Butaye, J., Hermy, M. (2001): Forest plant species richness in small, fragmented mixed deciduous forest patches: the role of area, time and disperal limitation - J. Biogeogr. 28: 801-812.

[51] Johansson, L. J., Hall, K., Prentice, H. C., Ihse, M., Reitalu, T., Sykes, M. T., Kindstrom, M. (2008): Semi-natural grassland continuity, long-term land-use change and plant species richness in an agricultural landscape on Oland, Sweden - Landscape Urban. Plan. 84: 200-211.

[52] Karger, D. N., Weigelt, P., Amoroso, V. B., Darnaedi, D., Hidayat, A., Kreft, H., Kessler, M. (2014): Island biogeography from regional to local scales: evidence for a spatially scaled echo pattern of fern diversity in the Southeast Asian archipelago - J Biogeogr. 41: 250-260.

[53] Kattan, G. H., Murcia, C. (2003): A review and synthesis of conceptual frameworks for the study of forest fragmentation - Ecol. Stud. 162: 183-200.

[54] Keshtkar, H., Voigt, W. (2016): Potential impacts of climate and landscape fragmentation changes on plant distributions: Coupling multi-temporal satellite imagery with GIS-based cellular automata model - Ecol. Inform. 32: 145-155.

[55] Kolb, A., Diekmann, M. (2004): Effects of environment, habitat configuration and forest continuity on the distribution of forest plant species - J. Veg. Sci. 15: 199-208.

[56] Kolb, A., Diekmann, M. (2005): Effects of life-history traits on responses of plant species to forest fragmentation - Conserv. Biol. 19(3): 929-938.

[57] Koszelnik-Leszek, A., Podlaska, M., Fudali, E., Tomaszewska, K. (2015): Diversity of the midfield forest island's flora in the rural landscape of the south-western Poland in relation to sociological-ecological groups - Scientific Papers of the University of Life Sciences in Wrocław. Agriculture 612: 29-55. (In Polish) 
[58] Krauss, J., Klein, A.-M., Stefan-Dewenter, I., Tscharntke, T. (2004): Effects of habitat area, isolation, and landscape diversity on plant species richness of calcareous grasslands - Biodivers. Conserv. 13: 1427-1439.

[59] Krausmann, F., Haberl, H., Schulz, N. B., Erb, K. H., Darge, E., Gaube, V. (2003): Landuse change and socio-economic metabolism in Austria. I: Driving forces of land-use change: 1950-1995 - Land Use Policy 20(1): 1-20.

[60] Kuussaari, M., Bommarco, R., Heikkinen, R. K., Helm, A., Krauss, J., Lindborg, R., Öckinger, E., Pärtel, M., Pino, J., Roda, F., Stefanescu, C., Teder, T., Zobel, M., SteffanDewenter, I. (2009): Extinction debt: a challenge for biodiversity conservation - Trends Ecol. Evol. 24(10): 564-571.

[61] Lindborg, R., Plue, J., Andersson, K., Cousins, S. A. O. (2014): Function of small habitat elements for enhancing plant diversity in different agricultural landscapes - Biol. Conserv. 169: 206-213.

[62] Lindenmayer, D. B., Fischer, J. (2006): Tackling the habitat fragmentation panchreston Trends Ecol. Evol. 22(3): 127-132.

[63] Löffler, F., Fartmann, T. (2017): Effects of landscape and habitat quality on Orthoptera assemblages of prealpine calcareous grasslands - Agric. Ecosyst. Environ. 248: 71-81.

[64] Lomba, A., Vaz, A. S., Moreira, F., Honrado, J. P. (2013): Hierarchic species-area relationships and the management of forest habitat islands in intensive farmland - Forest Ecol. Manag. 291: 190-198.

[65] Lomba, A., Vicente, J., Moreira, F., Honrado, J. (2011): Effects of multiple factors on plant diversity of forest fragments in intensive farmland of Northern Portugal - Forest Ecol. Manag. 262: 2219-2228.

[66] Longatti, P., Dalang, T. (2007): The meaning of "landscape" - an exegesis of swiss government texts. - In: Kienast, F., Wildi, O., Ghosh, S. (eds.) A Changing World. Challenges for Landscape Research: 35-46.

[67] Luo, T., Zhang, T., Wang, Z., Gan, Y. (2015): Driving Forces of Landscape Fragmentation due to Urban Transportation Networks: Lessons from Fujian, China - J. Urban Plann. Dev. 142(2): 04015013 1- 0401501313.

[68] Luoto, M., Rekolainen, S., Aakkula, J., Pykala, J. (2003): Loss of plant species richness and habitat connectivity in grassland associated witch agricultural change in Finland Ambio 32(7): 447-452.

[69] Löbel, S., Dengler, J., Hobohm, C. (2006): Species richness of vascular plants, bryophytes and lichens in dry grasslands: the effects of environment, landscape structure and competition - Folia Geobot. 41: 377-393.

[70] MacArthur, R., Wilson, E. O. (1967): The theory of island biogeography. -Princeton University Press, Princeton 203.

[71] Mathias, Ö., Cousins, S. A. O., Eriksson, O. (2007): Size and heterogeneity rather than landscape context determine plant species richness in semi-natural grasslands - J. Veg. Sci. 18: 859-868.

[72] Montis, de A., Martín, B., Ortega, E., Ledda, A., Serra, V. (2017): Landscape fragmentation in Mediterranean Europe: a comparative approach. -Land Use Policy 64: 83-94.

[73] Mortelliti, A., Amori, G., Boitani, L. (2010): The role of habitat quality in fragmented landscapes: a conceptual overview and prospectus for future research. - Oecologia 163: 537-547.

[74] Öckinger, E., Lindborg, R., Sjödin, N. E., Bommarco, R. (2012): Landscape matrix modifies richness of plants and insects in grassland fragments - Ecography 35: 259-267.

[75] Økland, R. H., Bratli, H., Dramstad, W. E., Edvardsen, A., Engan, G., Fjellstad, W., Heegaard, E., Pedersen, O., Solstad, H. (2006): Scale-dependent importance of environment, land use and landscape structure for species richness and composition of SE Norwegian modern agricultural landscapes - Landscape Ecol. 21: 969-987. 
[76] Opdam, P., Wascher, D. (2004): Climate change meets habitat fragmentation: linking landscape and biogeographical scale levels in research and conservation - Biol. Conserv. 117(3): 285-297.

[77] Orłowski, G., Nowak, L. (2005): Species composition of woody vegetation of three types of mid-field woodlots in intensively managed farmland (Wrocław plains, South-Western Poland) - Pol. J. Ecol. 53(1): 25-36.

[78] Petit, S., Griffiths, L., Smart, S. S., Smith, G. M., Stuart, R. C., Wright, S. M. (2004): Effects of area and isolation of woodland patches on herbaceous plant species richness across Great Britain - Landscape Ecol. 19: 463-471.

[79] Pieńkowski, P., Podlasiński, M. (2017): Dominating forms of land coveras regards to physical geographical division regions of Poland - Prace Komisji Krajobrazu Kulturowego 37: 105-116. (In Polish)

[80] Piessens, K., Honnay, O., Hermy, M. (2005): The role of fragment area and isolation in the conservation of heathland species - Biol. Conserv. 122: 61-69.

[81] Prach, K., Fajmon, K., Jongepierova, I., Rehounkova, K. (2015): Landscape context in colonization of restored dry grasslands by target species - Appl. Veg. Sci. 18: 181-189.

[82] Qi, K., Fan, Z., Ng, C. N., Wang, X., Xie, Y. (2017): Functional analysis of landscape connectivity at the landscape, component, and patch levels: A case study of Minqing County, Fuzhou City, China - Appl. Geogr. 80: 64-77.

[83] Quine, C.P., Watts, K. (2009): Successful de-fragmentation of woodland by planting in an agricultural landscape? An assessment based on landscape indicators - J. Environ. Manage. 90(1): 251-259.

[84] Raatikainen, K. M., Heikkinen, R. K., Luoto, M. (2009): Relative importance of habitat area, connectivity, management and local factors for vascular plants: spring ephemerals in boreal semi-natural grasslands - Biodivers. Conserv. 18: 1067-1085.

[85] Reitalu, T., Sykes, M. T., Johansson, L. J., Lonn, M., Hall, K., Vandewalle, M., Prentice, H. C. (2009): Small-scale plant species richness and evenness in semi-natural grasslands respond differently to habitat fragmentation - Biol. Conserv. 142: 899-908.

[86] Richling, A., Solon, J. (2011): Ekologia krajobrazu - Wyd. Nauk. PWN. Warszawa: 464. (In Polish)

[87] Ricketts, T. H. (2001): The matrix matters: effective isolation in fragmented landscapes Am. Nat. 158(1): 87-99.

[88] Shannon, C. E. (1948): A mathematical theory of communication - The Bell System Technical Journal 27.

[89] Sienkiewicz, J. (2010): Concepts of biodiversity - their dimensions and measures in the light of literature - Ochr. Śr. i Zasobów Nat. 45: 7-29. (In Polish)

[90] Simpson, E. H. (1949): Measurement of Diversity - Nature 163

[91] Solon, J., Chmielewski, T., Myga - Piątek, U., Kistowski, M. (2015): Identification and assessment of Polish landscapes - stages and methods of actions within the landscape audit in the administrative regions - Problemy ekologii krajobrazu 60: 55-76. (In Polish)

[92] Taylor, P. D., Fahrig, L., Henein, K., Merriam, G. (1993): Connectivity is a vital element of landscape structure - Oikos 68(3): 571-572.

[93] Tessel, S. M, Palmquist, K. A., Peet, R. K. (2016): Species-Area Relationships. (http://www.oxfordbibliographies.com/view/document/obo-9780199830060/obo9780199830060-0147.xml / accessed on 01.10.2018)

[94] Tscharntke, T., Klein, A. M., Kruess, A., Dewenter, I. S., Thies, C. (2005): Landscape perspectives on agricultural intensification and biodiversity - ecosystem service management - Ecol. Lett. 8: 857-874.

[95] Vallet, J., Beaujouan, V., Pithon, J., Rozé, F., Daniel, H. (2010): The effects of urban or rural landscape context and distance from the edge on native woodland plant communities - Biodivers. Conserv. 19: 3375-3392.

[96] Vellend, M., Verheyen, K., Flinn, K. M., Jacquemyn, H., Kolb A., van Calster, H., Peterken, G., Graae, B. J., Bellemare, J., Honnay, O., Brunet, J., Wulf, M., Gerhard, F., 
Hermy, M. (2007): Homogenization of forest plant communities and weakening of species-environment relationships via agricultural land use - J. Ecol. 95: 565-573.

[97] Verheyen, K., Vellend, M., von Calster, H., Peterken, G., Hermy, M. (2004): Metapopulation dynamics in changing landscapes: a new spatially realistic model for forest plants - Ecology 85(12): 3302-3312.

[98] Vieira, M. V., Olifiers, N., Delciellos, A. C., Antunes, V. Z., Bernardo, L. R., Grelle, C. E. V., Cerqueira, R. (2009): Land use vs. fragment size and isolation as determinants of small mammal composition and richness in Atlantic Forest remnants - Biol. Conserv. 142: 1191-1200.

[99] Waldén, E., Öckinger, E., Winsa, M., Lindborg, R. (2017): Effects of landscape composition, species pool and time on grassland specialists in restored semi-natural grasslands - Biol. Conserv. 214: 176-183.

[100] Watling, J. I., Donnelly, M. A. (2008): Species richness and composition of amphibians and reptiles in a fragmented forest landscape in northeastern Bolivia - Basic Appl. Ecol. 9: 523-532.

[101] Whittaker, R. H. (1972): Evolution and measurment of species diversity - Taxon 21(2/3): 213.

[102] Wiedmann, F., Salama, A. M., Thierstein, A. (2012): Urban evolution of the city of Doha: an investigation into the impact of economic transformations on urban structures $-\mathrm{J}$. Fac. Arch. 29(2): 35-61.

[103] Wiens, J. A. (1995): Habitat fragmentation - island vs landscape perspectives on bird conservation - Ibis 137: S97-S104.

[104] Williams, P., Whitfield, M., Biggs, J., Bray, S., Fox, G., Nicolet, P., Sear, D. (2004): Comparative biodiversity of rivers, streams, ditches and ponds in an agricultural landscape in Southern England - Biol. Conserv. 115(2): 329-341.

[105] Zarzycki, J. (2009): Methodological and technical innovation in phytosociological research - Łąkarstwo w Polsce 12: 233-247. (In Polish)

[106] Zulka, K. P., Abensperg-Traun, M., Milasowszky, N., Bieringer, G., Gereben-Krenn, B. A., Holzinger, G., Rabitsch, W., Reischutz, A., Querner, P., Sauberer, N., Schmitzberger, I., Willner, W., Wrbka, T., Zechmeister, H. (2014): Species richness in dry grassland patches of eastern Austria: A multi-taxon study on the role of local, landscape and habitat quality variables. - Agr. Ecosyst. Environ. 182: 25-36. 


\section{APPENDIX}

Appendix 1. Juxtaposition of studied area and research methods across different habitat types by various authors. $n / i-n o$ information

\begin{tabular}{|c|c|c|c|c|c|c|c|}
\hline \multicolumn{4}{|c|}{ Study area } & \multirow[b]{2}{*}{$\begin{array}{c}\text { Source of } \\
\text { data }\end{array}$} & \multirow[b]{2}{*}{$\begin{array}{l}\text { Variables involved in research } \\
\text { affecting species richness }\end{array}$} & \multirow[b]{2}{*}{ Data analysis } & \multirow[b]{2}{*}{ References } \\
\hline Location & $\begin{array}{l}\text { Studied area [ha] } \\
\text { 1) landscape } \\
\text { 2) patch } \\
\text { 3) transect } \\
\text { 4) plots/sample }\end{array}$ & $\begin{array}{l}\text { Type of } \\
\text { landscape } \\
\text { (matrix) }\end{array}$ & $\begin{array}{c}\text { Type/ No of } \\
\text { patches }\end{array}$ & & & & \\
\hline $\begin{array}{r}\text { Austria: } \\
\text { Panonian part } \\
\text { of eastern } \\
\text { Austria }\end{array}$ & $\begin{array}{l}\text { 1) } n / i \\
\text { 2) } 0,05-10,0 \\
\text { 3) } n / i \\
\text { 4) } n / i\end{array}$ & agricultural & $\begin{array}{l}\text { dry } \\
\text { grassland/ } 50\end{array}$ & field study & $\begin{array}{l}\text { size and shape measures, local } \\
\text { quality measures, area of } \\
\text { extensively used elements, area of } \\
\text { linear elements, distance to } \\
\text { mainland, area of extensive } \\
\text { grassland, area of fallow land, area } \\
\text { of short-grass dry grassland, area of } \\
\text { short-grass linear elements, } \\
\text { landscape heterogeneity }\end{array}$ & $\begin{array}{l}\text { 1) GIS, } \\
\text { 2) statistical calculations, } \\
\text { 3) species richness: No of } \\
\text { species }\end{array}$ & $\begin{array}{l}\text { Zulka et } \\
\text { al., } 2014\end{array}$ \\
\hline $\begin{array}{r}\text { Belgium: } \\
\text { Flanders, } \\
\text { (western part of } \\
\text { Belgium and } \\
\text { northern part of } \\
\text { France) }\end{array}$ & $\begin{array}{l}\text { 1) } n / i \\
\text { 2) } 0,5-5216 \\
\text { 3) } n / i \\
\text { 4) } n / i\end{array}$ & agricultural & forest/ 234 & field study & $\begin{array}{l}\text { area, shape, soli, slope, percentage } \\
\text { of ancient and recent forest, } \\
\text { isolation, distance to the nearest } \\
\text { neighbour }\end{array}$ & $\begin{array}{l}\text { 1) GIS, } \\
\text { 2) statistical calculations, } \\
\text { 3) species richness: No of } \\
\text { species }\end{array}$ & $\begin{array}{l}\text { Honnay et } \\
\text { al., } 1999\end{array}$ \\
\hline $\begin{array}{l}\text { Belgium: } \\
\text { Vlaams- } \\
\text { Brabant }\end{array}$ & $\begin{array}{l}\text { 1) } 4200 \text { ha } \\
\text { 2) } n / i \\
\text { 3) } n / i \\
\text { 4) } n / i\end{array}$ & agricultural & forest/ 241 & field study & $\begin{array}{l}\text { forest age, land use history, age } \\
\text { patches, forest area }\end{array}$ & $\begin{array}{l}\text { 1) GIS, } \\
\text { 2) statistical calculations, } \\
\text { 3) species richness: No of } \\
\text { species }\end{array}$ & $\begin{array}{l}\text { Jacquemyn } \\
\text { et al., } 2001\end{array}$ \\
\hline $\begin{array}{l}\text { Belgium: } \\
\text { Glabbeek }\end{array}$ & $\begin{array}{l}\text { 1) } n / i \\
\text { 2) } 0,1-11,4 \\
\text { 3) } n / i \\
\text { 4) } n / i\end{array}$ & agricultural & forest/ 241 & field study & $\begin{array}{l}\text { pasture exploatation, field } \\
\text { exploatation, topographical } \\
\text { diversity, isolation, structural } \\
\text { diversity, habitat diversity, soil } \\
\text { acidity, organic matter, nitrogen of } \\
\text { soil, plant available phosphorus, } \\
\text { C/N ratio of soil }\end{array}$ & $\begin{array}{l}\text { 1) GIS, } \\
\text { 2) statistical calculations, } \\
\text { 3) species richness: No of } \\
\text { species }\end{array}$ & $\begin{array}{l}\text { Dumortier } \\
\text { et al., } 2002\end{array}$ \\
\hline $\begin{array}{l}\text { Belgium: } \\
\text { Northwestern } \\
\text { part of }\end{array}$ & $\begin{array}{l}\text { 1) } 70000 \mathrm{ha} \\
\text { 2) } n / i \\
\text { 3) } n / i\end{array}$ & agricultural & $\begin{array}{l}\text { heathland/ } \\
153\end{array}$ & field study & $\begin{array}{l}\text { seed longevity index, mean plant } \\
\text { height, seed mass, dispersal mode, } \\
\text { growth form, self compatibility, }\end{array}$ & $\begin{array}{l}\text { 1) GIS, } \\
\text { 2) statistical calculations, } \\
\text { 3) species richness: No of }\end{array}$ & $\begin{array}{l}\text { Piessens et } \\
\text { al., } 2005\end{array}$ \\
\hline
\end{tabular}




\begin{tabular}{|c|c|c|c|c|c|c|c|}
\hline $\begin{array}{r}\text { Flanders, } \\
\text { in an area south } \\
\text { of Bruges }\end{array}$ & 4) $n / i$ & & & & $\begin{array}{l}\text { vegetative spread, seed numer, } \\
\text { isolation, light, soil moisture, pH } \\
\text { and soil nutrient status, Ellenberg } \\
\text { indicators }\end{array}$ & species & \\
\hline $\begin{array}{l}\text { Denmark: } \\
\text { Island Sjaelland }\end{array}$ & $\begin{array}{l}\text { 1) ca } 40000 \text { ha } \\
\text { 2) } n / i \\
\text { 3) } n / i \\
\text { 4) } n / i\end{array}$ & agricultural & grassland/ 85 & field study & $\begin{array}{l}\text { area, isolation, distance to the } \\
\text { nearest neighbour, soil pH, } \\
\text { potential solar radiation, anlge of } \\
\text { slope, seed mass, dispersal structure }\end{array}$ & $\begin{array}{l}\text { 1) GIS, } \\
\text { 2) statistical calculations, } \\
\text { 3) species richness: No of } \\
\text { species }\end{array}$ & $\begin{array}{l}\text { Brunn, } \\
2000 \mathrm{a}\end{array}$ \\
\hline $\begin{array}{l}\text { Denmark: } \\
\text { Island Sjaelland }\end{array}$ & $\begin{array}{l}\text { 1) ca } 40000 \text { ha } \\
\text { 2) } n / i \\
\text { 3) } n / i \\
\text { 4) } n / i\end{array}$ & agricultural & grassland/ 85 & field study & $\begin{array}{l}\text { area, isolation, distance to the } \\
\text { nearest neighbour, soil pH, } \\
\text { potential solar radiation, inclination } \\
\text { of slope }\end{array}$ & $\begin{array}{l}\text { 1) GIS, } \\
\text { 2) statistical calculations, } \\
\text { 3) species richness: No of } \\
\text { species }\end{array}$ & $\begin{array}{l}\text { Brunn, } \\
2000 b\end{array}$ \\
\hline $\begin{array}{l}\text { Denmark: } \\
\text { (i) Hornsherred } \\
\text { on Zealand and } \\
\text { (ii) Hmmerland } \\
\text { in Jutland }\end{array}$ & $\begin{array}{l}\text { 1) (i) } 48200 \\
\text { (ii) } 102900 \\
\text { 2) } 1-8000 \\
\text { 3) } n / i \\
\text { 4) } n / i\end{array}$ & agricultural & forest/ 82 & field study & $\begin{array}{l}\text { isolation, forest continuity, soli } \mathrm{pH} \text {, } \\
\text { tree species composition and seed } \\
\text { dispersal groups, quantity }\end{array}$ & $\begin{array}{l}\text { 1) GIS, } \\
\text { 2) statistical calculations, } \\
\text { 3) species richness: No of } \\
\text { species }\end{array}$ & $\begin{array}{l}\text { Graae, } \\
2000\end{array}$ \\
\hline $\begin{array}{l}\text { Estonia: } \\
\text { Saarema, Muhu }\end{array}$ & $\begin{array}{l}\text { 1) } n / i \\
\text { 2) } 1,0-340,0 \\
\text { 3) } n / i \\
\text { 4) } n / i\end{array}$ & agricultural & $\begin{array}{l}\text { alvar } \\
\text { grassland } \\
\text { patches, } 35\end{array}$ & field study & $\begin{array}{l}\text { past area, past connectivity, current } \\
\text { area, current connectivity }\end{array}$ & $\begin{array}{l}\text { 1) GIS, } \\
\text { 2) statistical calculations, } \\
\text { 3) species richness: No of } \\
\text { species }\end{array}$ & $\begin{array}{l}\text { Helm et al., } \\
2006\end{array}$ \\
\hline $\begin{array}{l}\text { Estonia: } \\
\text { Islands of } \\
\text { Saaremaa and } \\
\text { Muhu }\end{array}$ & $\begin{array}{l}\text { 1) } \mathrm{n} / \mathrm{i} \\
\text { 2) } \mathrm{n} / \mathrm{i} \\
\text { 3) } 33 \text { transects: } \\
\text { 10x01 m } \\
\text { 4) } \mathrm{n} / \mathrm{i}\end{array}$ & agricultural & grassland/ 33 & field study & $\begin{array}{l}\text { soil depth, } \mathrm{pH}, \text { temperature, } \\
\text { moisture and electrical } \\
\text { conductivity, relative light } \\
\text { availability, shrub cover, historical } \\
\text { habitat area connectivity and } \\
\text { availability }\end{array}$ & $\begin{array}{l}\text { 1) GIS, } \\
\text { 2) statistical calculations, } \\
\text { 3) species richness: No of } \\
\text { species }\end{array}$ & $\begin{array}{l}\text { Gazol et } \\
\text { al., } 2012\end{array}$ \\
\hline $\begin{array}{l}\text { Finland: } \\
\text { the Rekijoki } \\
\text { river valley }\end{array}$ & $\begin{array}{l}\text { 1) } n / i \\
\text { 2) }<5 \div>40 \\
\text { 3) } n / i \\
\text { 4) } n / i\end{array}$ & agricultural & grassland/ $\mathrm{n} / \mathrm{i}$ & field study & $\begin{array}{l}\text { patch area, connectivity, solar } \\
\text { radiation }\end{array}$ & $\begin{array}{l}\text { 1) GIS, } \\
\text { 2) statistical calculations, } \\
\text { 3) species richness: No of } \\
\text { species }\end{array}$ & $\begin{array}{l}\text { Raatikaine } \\
\text { n et al., } \\
2009\end{array}$ \\
\hline $\begin{array}{l}\text { Finalnd: } \\
\text { Somero }\end{array}$ & $\begin{array}{l}\text { 1) } 10000 \mathrm{ha} \\
\text { 2) } n / i \\
\text { 3) } n / i \\
\text { 4) } n / i\end{array}$ & agricultural & $\begin{array}{l}\text { grassland } \\
\text { patches/ } 289\end{array}$ & field study & habitat connectivity, grazing & $\begin{array}{l}\text { 1) GIS, } \\
\text { 2) statistical calculations, } \\
\text { 3) species richness: No of } \\
\text { species }\end{array}$ & $\begin{array}{l}\text { Luoto et } \\
\text { al., } 2003\end{array}$ \\
\hline $\begin{array}{l}\text { France: } \\
\text { Angers, Nantes }\end{array}$ & $\begin{array}{l}\text { 1) } \mathrm{n} / \mathrm{i} \\
\text { 2) } \mathrm{ca} 1,5 \\
\text { 3) } \mathrm{n} / \mathrm{i}\end{array}$ & urban/rural & $\begin{array}{l}\text { forest/ } 10 \\
{[5 \text { agr.; } 5} \\
\text { urban] }\end{array}$ & field study & $\begin{array}{l}\text { edge effect, distance from the edge } \\
\text { and urban-rural context, vegetation } \\
\text { structure, light and soil pH, total }\end{array}$ & $\begin{array}{l}\text { 1) -, } \\
\text { 2) statistical calculations, } \\
\text { 3) species richness: No of }\end{array}$ & $\begin{array}{l}\text { Vallet et } \\
\text { al., } 2010\end{array}$ \\
\hline
\end{tabular}




\begin{tabular}{|c|c|c|c|c|c|c|c|}
\hline & 4) $n / i$ & & & & $\begin{array}{l}\text { species richness, number of forest } \\
\text { specialists, forest generalists and } \\
\text { non-forest species; Ellenberg }\end{array}$ & species & \\
\hline $\begin{array}{r}\text { Germany: } \\
\text { Northwestern } \\
\text { part of the } \\
\text { country }\end{array}$ & $\begin{array}{l}\text { 1) } 36500 \text { ha } \\
\text { 2) } n / i \\
\text { 3) } n / i \\
\text { 4) } n / i\end{array}$ & agricultural & forest/ 145 & $\begin{array}{l}\text { field study; } \\
\text { check list }\end{array}$ & $\begin{array}{l}\text { abundance of each species, } \\
\text { topographic heterogeneity, soil, } \\
\text { habitat quality, configuration (area, } \\
\text { isolation/buffer, isolation/distance) } \\
\text { and continuity }\end{array}$ & $\begin{array}{l}\text { 1) GIS, } \\
\text { 2) statistical calculations, } \\
\text { 3) species richness: No of } \\
\text { species }\end{array}$ & $\begin{array}{l}\text { Kolb and } \\
\text { Diekmann, } \\
2004\end{array}$ \\
\hline $\begin{array}{l}\text { Germany: } \\
\text { Göttingen }\end{array}$ & $\begin{array}{l}\text { 1) } n / i \\
\text { 2) } 0,03-5,14 \\
\text { 3) } n / i \\
\text { 4) } n / i\end{array}$ & agricultural & $\begin{array}{l}\text { calcerous } \\
\text { grassland/ } 31\end{array}$ & field study & area, isolation, landscape diversity & $\begin{array}{l}\text { 1) -, } \\
\text { 2) statistical calculations, } \\
\text { 3) species richness: No of } \\
\text { species }\end{array}$ & $\begin{array}{l}\text { Krauss et } \\
\text { al., } 2004\end{array}$ \\
\hline $\begin{array}{r}\text { Germany: } \\
\text { Southeastern } \\
\text { part of the } \\
\text { country }\end{array}$ & $\begin{array}{l}\text { 1) (i) } 2500 \\
\text { (ii) } 1000 \\
\text { 2) } \mathrm{n} / \mathrm{i} \\
\text { 3) } \mathrm{n} / \mathrm{i} \\
\text { 4) } 10 \text { plots: } 2 \times 2 \\
\text { m }\end{array}$ & agricultural & $\begin{array}{l}\text { calcerous } \\
\text { grasslands/ } \\
18\end{array}$ & field study & $\begin{array}{l}\text { fragment area, area/perimeter ratio, } \\
\text { distance to the nearest calcareous } \\
\text { grassland, loss of calcareous } \\
\text { grassland, vegetation height (VH), } \\
\text { cover of grass (CG), litter (CL), } \\
\text { bare soil (BS) }\end{array}$ & $\begin{array}{l}\text { 1) GIS, } \\
\text { 2) statistical calculations, } \\
\text { 3) species richness: No of } \\
\text { species }\end{array}$ & $\begin{array}{l}\text { Huber et } \\
\text { al., } 2017\end{array}$ \\
\hline $\begin{array}{r}\text { Germany: } \\
\text { Northwestern } \\
\text { part oft he } \\
\text { country }\end{array}$ & $\begin{array}{l}\text { 1) } 36500 \text { ha } \\
\text { 2) }>1 \text { ha } \\
\text { 3) } n / i \\
\text { 4) } n / i\end{array}$ & agricultural & forest/ 145 & field study & $\begin{array}{l}\text { diaspore mass, seed-bank longevity, } \\
\text { dispersal structure, pollination } \\
\text { mode, plant height, life span, } \\
\text { habitat preference, connectivity, } \\
\text { area }\end{array}$ & $\begin{array}{l}\text { 1) GIS, } \\
\text { 2) statistical analysis, } \\
\text { 3) species richness: No of } \\
\text { species }\end{array}$ & $\begin{array}{l}\text { Kolb and } \\
\text { Diekmann, } \\
2005\end{array}$ \\
\hline $\begin{array}{l}\text { Great Britain: } \\
\text { (i) uplands, } \\
\text { (ii) lowlands }\end{array}$ & $\begin{array}{l}\text { 1) } \mathrm{n} / \mathrm{i} \\
\text { 2) mean: } \\
\text { (i) } 3,1 \\
\text { (ii) } 6,8 \\
\text { 3) } \mathrm{n} / \mathrm{i} \\
\text { 4) } \mathrm{n} / \mathrm{i}\end{array}$ & agricultural & forest/ 308 & $\begin{array}{l}\text { list of the } \\
120 \text { British } \\
\text { Ancient } \\
\text { Woodland } \\
\text { Indicator } \\
\text { species; } \\
\text { field study }\end{array}$ & $\begin{array}{l}\text { patch area, shape, isolation, the } \\
\text { length of hedgerows and lines of } \\
\text { trees in the } 1 \mathrm{~km} \text { square and the } \\
\text { area of woodland within } 500 \mathrm{~m} \text { of } \\
\text { the vegetation plot, Ellenberg } \\
\text { indicator values (pH, light, fertility) }\end{array}$ & $\begin{array}{l}\text { 1) GIS, } \\
\text { 2) statistical calculations, } \\
\text { 3) species richness: No of } \\
\text { species }\end{array}$ & $\begin{array}{l}\text { Petit et al., } \\
2004\end{array}$ \\
\hline $\begin{array}{r}\text { Great Britain: } \\
\text { central } \\
\text { Lincolnshire }\end{array}$ & $\begin{array}{l}\text { 1) } 93000 \text { ha } \\
\text { 2) } n / i \\
\text { 3) } n / i \\
\text { 4) } n / i\end{array}$ & agricultural & forest/ 326 & $\begin{array}{l}\text { The } \\
\text { Lincolnshir } \\
\text { e data set } \\
(155 \\
\text { species and } \\
326 \\
\text { patches) }\end{array}$ & 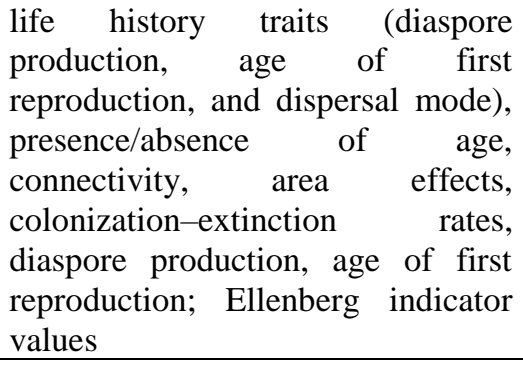 & $\begin{array}{l}\text { 1) -, } \\
\text { 2) statistical calculations, } \\
\text { 3) species richness: No of } \\
\text { species }\end{array}$ & $\begin{array}{l}\text { Verheyen } \\
\text { et al., } 2004\end{array}$ \\
\hline
\end{tabular}

APPLIED ECOLOGY AND ENVIRONMENTAL RESEARCH 17(1):53-83.

http://www.aloki.hu • ISSN 15891623 (Print) • ISSN 17850037 (Online)

DOI: http://dx.doi.org/10.15666/aeer/1701 053083

( 2019 , ALÖKI Kft., Budapest, Hungary 


\begin{tabular}{|c|c|c|c|c|c|c|c|}
\hline $\begin{array}{l}\text { Italy: } \\
\text { Veneto Region }\end{array}$ & $\begin{array}{l}\text { 1) } \mathrm{n} / \mathrm{i} \\
\text { 2) } 0,08-350 \\
\text { 3) } \mathrm{n} / \mathrm{i} \\
\text { 4) } 80 \quad \text { plots: } \\
8 \times 8 \mathrm{~m}\end{array}$ & $\begin{array}{l}\text { urban/ } \\
\text { industrial, } \\
\text { agricultural }\end{array}$ & $\begin{array}{l}80 \\
\text { georeference } \\
\text { d plots.; } \\
\text { forest/ } 59\end{array}$ & field study & $\begin{array}{l}\text { human disturbance: 'local scale' } \\
\text { and 'landscape scale', distance } \\
\text { from the forest edge, size and shape } \\
\text { of the patch }\end{array}$ & $\begin{array}{l}\text { 1) GIS, } \\
\text { 2) statistical calculations, } \\
\text { 3) species richness: No of } \\
\text { species }\end{array}$ & $\begin{array}{l}\text { Buffa et. } \\
\text { al., } 2018\end{array}$ \\
\hline Italy: & $\begin{array}{l}\text { 1) } n / i \\
\text { 2) } 4,0-37,0 \\
\text { 3) } n / i \\
\text { 4) } n / i\end{array}$ & agricultural & forest/ 211 & field study & $\begin{array}{l}\text { shape, isolation, forest age, habitat } \\
\text { quality (chemical properties of the } \\
\text { soil, number of additional habitats, } \\
\text { forest structure), grazing, } \\
\text { surrounding arable land }\end{array}$ & $\begin{array}{l}\text { 1) GIS, } \\
\text { 2) statistical calculations, } \\
\text { 3) species richness: vertical } \\
\text { evenness index, Shannon } \\
\text { formula }\end{array}$ & $\begin{array}{l}\text { De Sanctis } \\
\text { et al., } 2010\end{array}$ \\
\hline Luxembourg & $\begin{array}{l}\text { 1) } n / i \\
\text { 2) } 0,5-1,22 \\
\text { 3) } n / i \\
\text { 4) } n / i\end{array}$ & agricultural & $\begin{array}{l}\text { riverine } \\
\text { forest/ } 153\end{array}$ & field study & $\begin{array}{l}\text { forest age, depth of the reductive } \\
\text { layer, litter thickness, soil } \\
\text { productivity (Ellenberg values), soil } \\
\text { pH, connectivity, age at first } \\
\text { flowering, clonal propagation, } \\
\text { dispersal type, germination } \\
\text { requirement, life-forms, onset of } \\
\text { flowering, mean shoot height, } \\
\text { pollination vector, potential } \\
\text { mycorrhiza, seed longevity, seed } \\
\text { weight, seed production, size and } \\
\text { shape }\end{array}$ & $\begin{array}{l}\text { 1) GIS, } \\
\text { 2) statistical calculations, } \\
\text { 3) species richness: No of } \\
\text { species }\end{array}$ & $\begin{array}{l}\text { Hérault and } \\
\text { Honnay, } \\
2005\end{array}$ \\
\hline $\begin{array}{l}\text { Netherlands: } \\
\text { Province of } \\
\text { Drenthe }\end{array}$ & $\begin{array}{l}\text { 1) } n / i \\
\text { 2) } 0,04-770,9 \\
\text { 3) } n / i \\
\text { 4) } n / i\end{array}$ & agricultural & forest/ 312 & $\begin{array}{l}\text { species } \\
\text { data } \\
\text { obtained } \\
\text { from } \\
\text { survey } \\
\text { carried out } \\
\text { by the } \\
\text { Provincial } \\
\text { Governme } \\
\text { nt of } \\
\text { Drenthe } \\
\end{array}$ & $\begin{array}{l}\text { patch area, connectivity, isolation, } \\
\text { parameters of soli type and } \\
\text { groundwater level }\end{array}$ & $\begin{array}{l}\text { 1) GIS, } \\
\text { 2) statistical calculations, } \\
\text { 3) species richness: No of } \\
\text { species }\end{array}$ & $\begin{array}{l}\text { Grashof- } \\
\text { Bokdam, } \\
1997\end{array}$ \\
\hline $\begin{array}{l}\text { Norway: } \\
\text { (i) Vestfold, } \\
\text { Østfold, (ii) } \\
\text { Akershus, } \\
\text { Hedmark and } \\
\text { (iii) Oppland }\end{array}$ & $\begin{array}{l}\text { 1) } \mathrm{n} / \mathrm{i} \\
\text { 2) mean } \\
\text { (i) } 0,1972 \\
\text { (ii) } 0,0109 \\
\text { (iii) } 2, \mathrm{~h} \\
\text { 3) } \mathrm{n} / \mathrm{i}\end{array}$ & agricultural & $\begin{array}{l}\text { (i) } \\
\text { seminatural/ } \\
\text { 160; } \\
\text { (ii) midfield } \\
\text { islets/ 144; } \\
\text { (iii) forest }\end{array}$ & field study & $\begin{array}{l}\text { geographical, area, perimeter, shape } \\
\text { index, habitat diversity, land-use, } \\
\text { human impact, Ellenberg indicators }\end{array}$ & $\begin{array}{l}\text { 1) GIS, } \\
\text { 2) statistical calculations, } \\
\text { 3) species richness: No of } \\
\text { species }\end{array}$ & $\begin{array}{l}\text { Bratli et al., } \\
2006\end{array}$ \\
\hline
\end{tabular}

APPLIED ECOLOGY AND ENVIRONMENTAL RESEARCH 17(1):53-83.

http://www.aloki.hu • ISSN 15891623 (Print) • ISSN 17850037 (Online)

DOI: http://dx.doi.org/10.15666/aeer/1701 053083

(c) 2019, ALÖKI Kft., Budapest, Hungary 


\begin{tabular}{|c|c|c|c|c|c|c|c|}
\hline & 4) $n / i$ & & 245 & & & & \\
\hline $\begin{array}{l}\text { Norway: } \\
\text { Southeastern } \\
\text { part of the } \\
\text { country }\end{array}$ & $\begin{array}{l}\text { 1) } \mathrm{n} / \mathrm{i} \\
\text { 2) } \mathrm{n} / \mathrm{i} \\
\text { 3) } \mathrm{n} / \mathrm{i} \\
\text { 4) } 43 \text { plots: } 1,0 \\
\text { ha each }\end{array}$ & agricultural & $\begin{array}{l}\text { grassland/ } \\
282 \\
\text { midfield } \\
\text { islets, } 144 \\
\text { road verges, } \\
238 \\
\text { forest } \\
\text { patches, } 254 \\
\text { ponds, } 9\end{array}$ & field study & $\begin{array}{l}\text { area, shape index, landscape } \\
\text { heterogeneity, habitat diversity, } \\
\text { ecological factors (Ellenberg } \\
\text { values: light, moisture, reaction, } \\
\text { nitrogen), land-use intensity }\end{array}$ & $\begin{array}{l}\text { 1) GIS - ArcView, } \\
\text { 2) statistical calculations, } \\
\text { 3) species richness: No of } \\
\text { species }\end{array}$ & $\begin{array}{l}\text { Økland et } \\
\text { al., } 2006\end{array}$ \\
\hline $\begin{array}{l}\text { Norway: } \\
\text { Ornes in } \\
\text { Lustrafjorden }\end{array}$ & $\begin{array}{l}\text { 1) } n / i \\
\text { 2) mean: } 0,75 \\
\text { 3) } n / i \\
\text { 4) } n / i\end{array}$ & agricultural & $\begin{array}{l}\text { semi-natural } \\
\text { grassland/ } \\
20 ; \text { midfield } \\
\text { islets/ } 18 ; \\
\text { forest/ } 21\end{array}$ & field study & $\begin{array}{l}\text { patch area, patch perimeter, shape } \\
\text { index, canopy height, tree layer } \\
\text { cover, shrub layer cover, average } \\
\text { Ellenberg moisture, long-term } \\
\text { management intensity, agricultural } \\
\text { use, presence of wire, presence of } \\
\text { boulders, continuity }\end{array}$ & $\begin{array}{l}\text { 1) GIS, } \\
\text { 2) statistical calculations, } \\
\text { 3) species richness: gamma } \\
\text { diveristy }\end{array}$ & $\begin{array}{l}\text { Hamre et } \\
\text { al., } 2010\end{array}$ \\
\hline $\begin{array}{l}\text { Poland: } \\
\text { Nowogard } \\
\text { plains }\end{array}$ & $\begin{array}{l}\text { 1) } n / i \\
\text { 2) } 0,01-1,0 \\
\text { 3) } n / i \\
\text { 4) } n / i\end{array}$ & agricultural & ponds/ 53 & field study & matrix & $\begin{array}{l}\text { 1) GIS, } \\
\text { 2) -, } \\
\text { 3) species richness: No of } \\
\text { species }\end{array}$ & $\begin{array}{l}\text { Bosiacka } \\
\text { and } \\
\text { Pieńkowski } \\
, 2004 \\
\end{array}$ \\
\hline $\begin{array}{r}\text { Poland: } \\
\text { Southwestern } \\
\text { part of the } \\
\text { country }\end{array}$ & $\begin{array}{l}\text { 1) } n / i \\
\text { 2) } 0,03-15,08 \\
\text { 3) } n / i \\
\text { 4) } n / i\end{array}$ & agricultural & forest/ 74 & field study & $\begin{array}{l}\text { area, dispersal mode, origin of the } \\
\text { species (native/exotic), }\end{array}$ & $\begin{array}{l}\text { 1) GIS, } \\
\text { 2) statistical calculations, } \\
\text { 3) species richness: No of } \\
\text { species }\end{array}$ & $\begin{array}{l}\text { Orłowski } \\
\text { and Nowak } \\
2005\end{array}$ \\
\hline $\begin{array}{l}\text { Poland: } \\
\text { the Szczecin } \\
\text { Hills }\end{array}$ & $\begin{array}{l}\text { 1) } n / i \\
\text { 2) } 0,01-1,2 \\
\text { 3) } n / i \\
\text { 4) } n / i\end{array}$ & agricultural & ponds/ 50 & field study & $\begin{array}{l}\text { pond size, isolation, species } \\
\text { richness }\end{array}$ & $\begin{array}{l}\text { 1) GIS, } \\
\text { 2) statistical calculations, } \\
\text { 3) species richness: No of } \\
\text { species }\end{array}$ & $\begin{array}{l}\text { Bosiacka } \\
\text { and } \\
\text { Pieńkowski } \\
, 2012\end{array}$ \\
\hline $\begin{array}{l}\text { Poland: } \\
\text { Southwestern } \\
\text { part of the } \\
\text { country }\end{array}$ & $\begin{array}{l}\text { 1) } n / i \\
\text { 2) } 0,07-15,8 \\
\text { 3) } n / i \\
\text { 4) } n / i\end{array}$ & agricultural & forest/ 23 & field study & area, shape, matrix & $\begin{array}{l}\text { 1) -, } \\
\text { 2) -, } \\
\text { 3) species richness: No of } \\
\text { species }\end{array}$ & $\begin{array}{l}\text { Koszelnik- } \\
\text { Leszek et } \\
\text { al., } 2015\end{array}$ \\
\hline $\begin{array}{l}\text { Poland: } \\
\text { (i) Nowogard } \\
\text { and } \\
\text { (ii) Goleniów } \\
\text { plains }\end{array}$ & $\begin{array}{l}\text { 1) (i) } 900 \\
\text { (ii) } 900 \\
\text { 2) } n / i \\
\text { 3) } n / i \\
\text { 4) } n / i\end{array}$ & agricultural & $\begin{array}{l}\text { ponds/ 13; } \\
\text { grasslands/ } \\
4 ; \text { roadside } \\
\text { verges/ } 16\end{array}$ & field study & $\begin{array}{l}\text { habitat quality, neighbourhood } \\
\text { (matrix) }\end{array}$ & $\begin{array}{l}\text { 1) GIS, } \\
\text { 2) -, } \\
\text { 3) species richness: No of } \\
\text { species }\end{array}$ & $\begin{array}{l}\text { Gamrat et } \\
\text { al., } 2017\end{array}$ \\
\hline Portugal: & 1) $n / i$ & agricultural & forest/ 50 & field study & forest type (dominated by pines, & 1) GIS, & Lomba \\
\hline
\end{tabular}

APPLIED ECOLOGY AND ENVIRONMENTAL RESEARCH 17(1):53-83.

http://www.aloki.hu • ISSN 15891623 (Print) • ISSN 17850037 (Online)

DOI: http://dx.doi.org/10.15666/aeer/1701 053083

(c) 2019, ALÖKI Kft., Budapest, Hungary 


\begin{tabular}{|c|c|c|c|c|c|c|c|}
\hline $\begin{array}{l}\text { Metropolitan } \\
\text { Area of Porto }\end{array}$ & $\begin{array}{l}\text { 2) } 0,3-3,0 \\
\text { 3) } \mathrm{n} / \mathrm{i} \\
\text { 4) } \mathrm{n} / \mathrm{i}\end{array}$ & & & & $\begin{array}{l}\text { eucalypts, or both) , patch area, } \\
\text { patch shape, diameter at breast } \\
\text { height, tree density per hectare, } \\
\text { percentage cover of vegetation } \\
\text { strata, forest naturalness }\end{array}$ & $\begin{array}{l}\text { 2) statistical calculations, } \\
\text { 3) species richness: No of } \\
\text { species }\end{array}$ & al., 2011 \\
\hline $\begin{array}{l}\text { Portugal: } \\
\text { Metropolitan } \\
\text { Area of Porto }\end{array}$ & $\begin{array}{l}\text { 1) } n / i \\
\text { 2) } 0,3-3,0 \\
\text { 3) } n / i \\
\text { 4) } n / i\end{array}$ & agricultural & forest/ 50 & field study & $\begin{array}{l}\text { forest type (dominated by pines, } \\
\text { eucalypts, or both), area, impact of } \\
\text { forest naturalness on species-area } \\
\text { relationships }\end{array}$ & $\begin{array}{l}\text { 1) GIS, } \\
\text { 2) statistical calculations, } \\
\text { 3) species richness: No of } \\
\text { species }\end{array}$ & $\begin{array}{l}\text { Lomba et } \\
\text { al., } 2013\end{array}$ \\
\hline $\begin{array}{l}\text { Sweden: } \\
\text { (i) Island of } \\
\text { Selaon } \\
\text { (ii) Island of } \\
\text { Nynas }\end{array}$ & $\begin{array}{l}\text { 1) (i) } 2500 \\
\text { (ii) } 1000 \\
\text { 2) } n / i \\
\text { 3) } n / i \\
\text { 4) } n / i\end{array}$ & $\begin{array}{l}\text { (i) modern } \\
\text { rural, } \\
\text { (ii) traditional } \\
\text { rural }\end{array}$ & $\begin{array}{l}\text { (i) road } \\
\text { verges/ } 40 ; \\
\text { midfield } \\
\text { islets/ } 176, \\
\text { (ii) road } \\
\text { verges/ } 40, \\
\text { midfield } \\
\text { islets/ 53 }\end{array}$ & field study & $\begin{array}{l}\text { isolation, habitat area, past and } \\
\text { present land use, landscape context }\end{array}$ & $\begin{array}{l}\text { 1) Geographical Information } \\
\text { System (GIS), } \\
\text { 2) statistical calculations, } \\
\text { 3) species richness: number of } \\
\text { species }\end{array}$ & $\begin{array}{l}\text { Cousins, } \\
2006\end{array}$ \\
\hline $\begin{array}{l}\text { Sweden: } \\
\text { Island of Oland }\end{array}$ & $\begin{array}{l}\text { 1) } \mathrm{n} / \mathrm{i} \\
\text { 2) } \mathrm{n} / \mathrm{i} \\
\text { 3) } \mathrm{n} / \mathrm{i} \\
\text { 4) } 452 \text { sample } \\
\text { plots: } 2 \times 2 \mathrm{~m}\end{array}$ & agricultural & $\begin{array}{l}\text { grassland/ } \\
452 \text { sample } \\
\text { plots }\end{array}$ & field study & $\begin{array}{l}\text { soil depth and } \mathrm{pH} \text {, } \\
\text { microtopography, cover of bare } \\
\text { rock, cover of vegetation, grazing, } \\
\text { mowing, isolation, edge-to-edge } \\
\text { distance to the nearest different } \\
\text { grassland patch and the } \\
\text { connectivity index }\end{array}$ & $\begin{array}{l}\text { 1) GIS, } \\
\text { 2) statistical calculations, } \\
\text { 3) species richness: No of } \\
\text { species }\end{array}$ & $\begin{array}{l}\text { Löbel et } \\
\text { al., } 2006\end{array}$ \\
\hline $\begin{array}{l}\text { Sweden: } \\
\text { County of } \\
\text { Sodermanland }\end{array}$ & $\begin{array}{l}\text { 1) } n / i \\
\text { 2) } 0,42-6,31 \\
\text { 3) } n / i \\
\text { 4) } n / i\end{array}$ & agricultural & $\begin{array}{l}\text { semi-natural } \\
\text { grassland/ } 25\end{array}$ & field study & $\begin{array}{l}\text { area-effects, species density, } \\
\text { isolation, patch connectivity, } \\
\text { grazing }\end{array}$ & $\begin{array}{l}\text { 1) GIS, } \\
\text { 2) statistical calculations, } \\
\text { 3) species richness: No of } \\
\text { species }\end{array}$ & $\begin{array}{l}\text { Cousins et } \\
\text { al., } 2007\end{array}$ \\
\hline $\begin{array}{l}\text { Sweden: } \\
\text { Southern part } \\
\text { oft he country }\end{array}$ & $\begin{array}{l}\text { 1) } \mathrm{n} / \mathrm{i} \\
\text { 2) } 0,2-18,9 \\
\text { 3) } \mathrm{n} / \mathrm{i} \\
\text { 4) } \mathrm{n} / \mathrm{i}\end{array}$ & $\begin{array}{l}\text { agricultural/ } \\
\text { forest }\end{array}$ & grassland/ 30 & field study & $\begin{array}{l}\text { area, number of vegetation types, } \\
\text { proportion of forest, linear } \\
\text { elements, connectivity, historical } \\
\text { connectivity }\end{array}$ & $\begin{array}{l}\text { 1) GIS, } \\
\text { 2) statistical calculations, } \\
\text { 3) species richness: No of } \\
\text { species }\end{array}$ & $\begin{array}{l}\text { Mathias et } \\
\text { al., } 2007\end{array}$ \\
\hline $\begin{array}{l}\text { Sweden: } \\
\text { Island of Oland }\end{array}$ & $\begin{array}{l}\text { 1) } n / i \\
\text { 2) } 0,13-39,91 \\
\text { 3) } n / i \\
\text { 4) } n / i\end{array}$ & agricultural & grassland/ 55 & field study & $\begin{array}{l}\text { grazing intensity, cover of shrubs } \\
\text { and trees, the percentages of } \\
\text { grassland/ forest/ arable land, } \\
\text { geographic position of the } \\
\text { vegetation plots: } x \text { (East) and } y \\
\text { (North), their interaction term }\end{array}$ & $\begin{array}{l}\text { 1) GIS, } \\
\text { 2) statistical calculations, } \\
\text { 3) species richness: Shannon- } \\
\text { Wiener index, Shannon } \\
\text { evenness }\end{array}$ & $\begin{array}{l}\text { Reitalu et } \\
\text { al., } 2009\end{array}$ \\
\hline
\end{tabular}




\begin{tabular}{|c|c|c|c|c|c|c|c|}
\hline & & & & & (East*North) & & \\
\hline $\begin{array}{l}\text { Sweden: } \\
\text { Island of Oland }\end{array}$ & $\begin{array}{l}\text { 1) } \mathrm{n} / \mathrm{i} \\
\text { 2) } \mathrm{n} / \mathrm{i} \\
\text { 3) } \mathrm{n} / \mathrm{i} \\
\text { 4) } 451 \text { plots: } \\
\text { 50x50cm }\end{array}$ & agricultural & $\begin{array}{l}\text { grassland/ } \\
98 ; 451 \text { plots }\end{array}$ & field study & $\begin{array}{l}\text { past and present land-use/cover, } \\
\text { total habitat area, mean patch size, } \\
\text { maximum patch size, patch density, } \\
\text { Euclidian nearest neighbour } \\
\text { distance, continuity }\end{array}$ & $\begin{array}{l}\text { 1) GIS, } \\
\text { 2) statistical calculations, } \\
\text { 3) species richness: No of } \\
\text { species }\end{array}$ & $\begin{array}{l}\text { Johansson } \\
\text { et al., } 2008\end{array}$ \\
\hline $\begin{array}{l}\text { Sweden: } \\
\text { the counties of } \\
\text { Österg ötland } \\
\text { and Uppland }\end{array}$ & $\begin{array}{l}\text { 1) } n / i \\
\text { 2) } 1,0-10,0 \\
\text { 3) } n / i \\
\text { 4) } n / i\end{array}$ & $\begin{array}{l}\text { agricultural/m } \\
\text { ixed/ forest }\end{array}$ & grassland/ 45 & field study & patch area, isolation, matrix type & $\begin{array}{l}\text { 1) GIS, } \\
\text { 2) statistical calculations, } \\
\text { 3) species richness: No of } \\
\text { species }\end{array}$ & $\begin{array}{l}\text { Öckinger et } \\
\text { al., } 2012\end{array}$ \\
\hline $\begin{array}{l}\text { Sweden: } \\
\text { (i) Selaön, } \\
\text { (ii) Öllösa } \\
\text { (iii) Nynäs }\end{array}$ & $\begin{array}{l}\text { 1) } n / i \\
\text { 2) mean area: } \\
\text { (i) } 0,0233 \mathrm{ha} \text {, } \\
\text { (ii) } 0,0187 \mathrm{ha} \text {, } \\
\text { (iii) } 0,0299 \mathrm{ha} \\
\text { 3) } \mathrm{n} / \mathrm{i} \\
\text { 4) } \mathrm{n} / \mathrm{i}\end{array}$ & $\begin{array}{l}\text { (i) modern } \\
\text { agricultural } \\
\text { landscape; } \\
\text { (ii) modern } \\
\text { forested } \\
\text { landscape; } \\
\text { (iii) } \\
\text { traditional } \\
\text { landscape }\end{array}$ & $\begin{array}{l}\text { semi-natural } \\
\text { grassland: } \\
\text { (i) 20, (ii) } 20 \text {, } \\
\text { (iii) } 20 \text {; } \\
\text { midfield } \\
\text { islets: (i) } 25, \\
\text { (ii) 25, (iii) } \\
23 \text {; road } \\
\text { verges: (i) } \\
\begin{array}{ll}\text { (ii) } 22, \\
\text { (iii) 22 }\end{array}\end{array}$ & field study & $\begin{array}{l}\text { canopy height, specific leaf area, } \\
\text { seed production, lifespan, clonal } \\
\text { propagation, dispersal model }\end{array}$ & $\begin{array}{l}\text { 1) GIS, } \\
\text { 2) statistical calculations, } \\
\text { 3) species richness: beta } \\
\text { diversity }\end{array}$ & $\begin{array}{l}\text { Lindborg et } \\
\text { al., } 2014\end{array}$ \\
\hline
\end{tabular}


Appendix 2. Habitat loss and fragmentation papers by journal

\begin{tabular}{|l|l|l|}
\hline Journal & Total & $\%$ Total \\
\hline Journal of Vegetation Science & 5 & 12.20 \\
\hline Biological Conservation & 5 & 12.20 \\
\hline Agriculture, Ecosystems \& Environment & 3 & 7.32 \\
\hline Ecography & 3 & 7.32 \\
\hline Biodiversity and Conservation & 3 & 7.32 \\
\hline Forest Ecology and Management & 3 & 7.32 \\
\hline Landscape Ecology & 3 & 7.32 \\
\hline Acta Oecologica & 2 & 4.88 \\
\hline Journal of Biogeography & 2 & 4.88 \\
\hline A Journal of the Human Environment (AMBIO ) & 1 & 2.44 \\
\hline Ecology & 1 & 2.44 \\
\hline Conservation Biology & 1 & 2.44 \\
\hline Ecology Letters & 1 & 2.44 \\
\hline Landscape and Urban Planning & 1 & 2.44 \\
\hline Folia Geobotanica & 1 & 2.44 \\
\hline Diversity and Distributions & 1 & 2.44 \\
\hline Dissertations of Cultural Landscape Commission & 1 & 2.44 \\
\hline Hydrobiologia & 1 & 2.44 \\
\hline Polish Journal of Ecology & 1 & 2.44 \\
\hline Water-Environment-Rural Areas & 1 & 2.44 \\
\hline Scientific Papers of the University of Life Sciences in Wrocław. & 2.44 \\
\hline Agriculture & 1 & \\
\hline
\end{tabular}

